NBER WORKING PAPER SERIES

\title{
WERE TRADE AND FACTOR MOBILITY SUBSTITUTES IN HISTORY?
}

William J. Collins

Kevin H. O'Rourke

Jeffrey G. Williamson

Working Paper 6059

\section{NATIONAL BUREAU OF ECONOMIC RESEARCH \\ 1050 Massachusetts Avenue \\ Cambridge, MA 02138 \\ June 1997}

We acknowledge with thanks the help of Don Davis, Riccardo Faini, Elhanan Helpman, Arye Hillman, Jim Markusen, Giani Toniolo, Tony Venables, Klaus Zimmermann and participants at the Centre for Policy Research Conference on Trade and Factor Mobility, Venice (January 23-26, 1997). This paper has been revised extensively from the conference version, and it will be published in a CEPR volume (Cambridge University Press 1997) edited by Jaime de Melo, Riccardo Faini and Klaus Zimmerman. This paper is part of NBER's research programs in the Development of the American Economy and International Trade and Investment. Any opinions expressed are those of the authors and not those of the National Bureau of Economic Research.

(C) 1997 by William J. Collins, Kevin H. O'Rourke and Jeffrey G. Williamson. All rights reserved. Short sections of text, not to exceed two paragraphs, may be quoted without explicit permission provided that full credit, including $(\mathcal{C}$ notice, is given to the source. 
Were Trade and Factor Mobility Substitutes

in History?

William J. Collins, Kevin H. O'Rourke

and Jeffrey G. Williamson

NBER Working Paper No. 6059

June 1997

JEL Nos. F1, F2, N7

Development of the American Economy

and International Trade and Investment

\section{ABSTRACT}

Trade theorists have come to understand that their theory is ambiguous on the question: Are trade and factor flows substitutes? While this sounds like an open invitation for empirical research, hardly any serious econometric work has appeared in the literature. This paper uses history to fill the gap. It treats the experience of the Atlantic economy between 1870 and 1940 as panel data with almost seven hundred observations. When shorter run business cycles and "long swings" are extracted from the panel data, substitutability is soundly rejected. When secular relationships are extracted over longer time periods and across trading partners, once again substitutability is soundly rejected. Finally, the paper explores immigration policy and finds that policy makers never behaved as if they viewed trade and immigration as substitutes.

William J. Collins Department of Economics Harvard University Cambridge, MA 02138 wcollins@husc3.harvard.edu
Kevin H. O'Rourke Department of Political Economy University College Belfield, Dublin 4 IRELAND kevin.orourke@ucd.ie
Jeffrey G. Williamson Department of Economics 216 Littauer Harvard University Cambridge, MA 02138 and NBER jwilliam@fas.harvard.edu 
"Did the growth of protection in the late nineteenth century in North America stimulate the large labor and capital inflows of that period (assuming land to have been the abundant factor)? Did the increased protection in Britain in this century stimulate capital export? Did the breakdown in international factor movements in the interwar period stimulate trade?" Mundell (1957, p. 335)

Robert Mundell's seminal article on "International Trade and Factor Mobility" was published exactly forty years ago, and its conclusion threw down a challenge: Can history tell us whether (and when) trade and factor mobility are substitutes? Forty years seems long enough to wait, so this paper finally rises to Mundell's challenge by interpreting trade theory in the light of history and by investigating empirically the connection between trade and factor flows in the Atlantic economy between 1870 and 1940. The epoch prior to World War I is especially interesting in this regard since it is a liberal world environment providing a good natural experiment.

In the forty years since Mundell wrote, trade theorists have come to understand that theory is ambiguous on this issue. Whether trade and factor mobility are complements or substitutes depends on the assumptions made in the theory. If ever there was an open invitation for empirical research, this surely is it. Yet, few efforts have been made to identify econometrically the complementarity or substitutability between factor flows and international trade (see Wong 1988). Perhaps history may prove to be a valuable guide to choosing among these assumptions. But if theory is ambiguous, history may be too: the appropriate model for one historical period may not be the appropriate model for another. After all, there may be regime switches in history which correspond to alternative assumptions which trade theorists invoke to yield complementarity or substitutability. Nonetheless, even if history cannot identify the "right" model for thinking about international trade and factor mobility in the 1990s, it certainly can provide valuable insights into the nature of the connection and, by extension, illuminate important aspects of the contemporary phenomenon.

The first section of this paper briefly discusses the theoretical 
ambiguity concerning trade and factor mobility within relatively simple models: it overlaps a bit with Anthony Venables' paper in this volume, but we need to cover the same ground independently so as to motivate the economic history. The remainder of the paper will use that theory to explore the experience of three New World countries and seven old World countries between 1870 and 1940. We approach the data from two angles. First, we focus on business cycles and what the literature of the 1950 s and 1960 s called "long swings", the latter exhibiting booms and busts over fifteen to twenty year periods. Our interest is whether there was strict substitutability over the long swing between trade on the one hand and capital and migration flows on the other, and, if not, whether there is any evidence of complementarity; whether the resource abundant New World and resource scarce Old World obeyed the same laws of complementarity or substitutability; and whether there was a regime switch around World War I, after which frontiers are said to have "disappeared" and the world economy de-globalized. Second, we investigate the trade versus factor flow relationship using decade-averaged panel data, thus shifting the focus from shorter-run relationships generated by macroinstability in the time-series to longer-run relationships manifested over decades and across trading partners of widely different endowments. Finally, the paper turns to policy experience, and asks: Did New World policy makers act as if they viewed migration and trade as substitutes?

\section{Theory}

In order to guide the economic history in this paper, this section will discuss whether and when trade and factor mobility should be substitutes or complements within the context of standard trade theory. The Venables contribution to this volume tackles the question by deriving the effects of (possibly small) reductions in the costs of trade or factor mobility. We are interested in the same issues, but, for the sake of simplicity, consider more dramatic changes in transport costs. Throughout, we are interested in two 
questions: First, when countries move from autarchy to free trade, does the incentive for factors to migrate increase or diminish? Second, when countries move from factor immobility to active participation in global factor markets, does the volume of trade increase or diminish? Unlike the Venables chapter, we only consider constant returns to scale models, so that trade is due solely to endowment or technology differences between countries. This is more likely to have been true for our period than for the late 20 th century; Estevadeordal (1993) shows that endowments do a very good job of explaining international trade on the eve of World War $I$.

\section{$2 \times 2$ Models}

The relationship between trade and factor mobility in the standard $2 \times 2$ model is well known. (We refer to the $2 \times 2$ model rather than the Heckscherohlin model, since Heckscher and ohlin had in mind a far richer structure than that developed by Lerner, Samuelson, Rybczynski and the rest of their followers.) Let Britain and Ireland produce machines and textiles, using labor and capital. Textile production is relatively labor-intensive, and Ireland is relatively labor-abundant. Wages are initially low in Ireland and high in Britain, while profits are higher in Ireland. When trade opens up, Ireland exports textiles and imports machines. Wages rise in Ireland and fall in Britain, while profits fall in Ireland and rise in Britain, implying that trade induces factor price convergence (Ohlin 1924 reprinted in Flam and Flanders 1991). Under restrictive circumstances, there will be complete factor price equalization (Heckscher 1919, Lerner 1952, Samuelson 1949 ). Trade reduces or completely eliminates the incentive for labor to move to Britain, and for capital to flow to Ireland; and therefore, trade and factor mobility are substitutes.

Alternatively, it is clear that factor mobility tends to equalize endowments across countries, raising Irish capital-labor ratios and lowering British capital-labor ratios. Factor mobility thus erodes the basis for trade (Mundell 1957). Once again, the conclusion is that trade and factor mobility 
are substitutes.

As Markusen (1983) has shown, these classic results are derived from the assumption that factor endowments alone are the basis for trade: countries are assumed to be otherwise identical. If the basis for trade is some other difference between countries, trade and factor flows can be complements, even in the context of $2 \times 2$ models. Markusen' $s$ most intuitive demonstration of this principle concerns differences in technology between countries. Now let Ireland and Britain have identical factor endowments, but also let technology in the British machine industry be (Hicks-neutral) superior to that in the Irish machine industry. Britain will have a comparative advantage in machine production. When trade opens up, Britain will export machines: an increase in capital-intensive machine production will increase the demand for capital in Britain, hence raising British profits and lowering British wages. When Ireland specializes in textiles, Irish wages rise and Irish profits fall. Markusen shows that in trade equilibrium, wages are higher in Ireland, while profits are higher in Britain. ${ }^{1}$ Now allow factors to flow in response to factor price differentials. Capital will flow from Ireland to Britain, and labor from Britain to Ireland. In line with the Rybczynski (1955) theorem, machine production in Britain will expand, and British textile production will contract, while the opposite production responses will occur in Ireland. This will further increase British exports of machines, and imports of textiles. Factor mobility has increased trade. Thus, trade and factor mobility are complements.

\section{The Specific Factors and $3 \times 2$ Models}

Heckscher and ohlin were motivated by the intercontinental exchange of food for manufactured goods that characterized the late 19th century. Landscarce and labor-abundant Europe exported manufactures to the resourceabundant, labor-scarce New World, in exchange for grain, wool, raw cotton, and

1 Textile production is higher in Ireland than in Britain. It follows that capital-labor ratios are higher in Irish than in British textile production, which implies higher wages and lower profits in Ireland. 
other agricultural products. Obviously, it is difficult to rationalize such trade in the context of simple $2 \times 2$ models: land, labor and capital were all relevant factors of production. In 1966, an economic historian, Peter Temin, wrote a paper on ante bellum Anglo-American industry in which he assumed that manufactured goods were produced with labor and capital, while food was produced with labor and land. This model was fully developed by Jones (1971), and dubbed the specific factors model of trade. We draw attention to the cliometric antecedents of this model, not just out of team spirit, but in order to highlight a theme of this paper: the 'correct' trade model may vary with the period being studied.

The relationship between trade and factor mobility in the specific factors model is ambiguous. Imagine two economies, Europe and America, and to keep matters simple, assume that they only differ in their land endowments: America has more land. What does this imply for American autarchic factor prices, relative to European factor prices? ${ }^{2}$

One way to answer this question is to distinguish between factor mobility responses and price effects due to differences in land availability (following Corden and Neary 1982).3 with more land, the marginal product of labor in agriculture increases. Wages increase in both sectors, as labor moves into agriculture, and profits as well as rents decline. On the other hand, more land increases the supply of food relative to manufactured goods. This will lower the relative price of food, tending to lower rents but increase profits. American rents will definitely be lower than European rents, but American profits may be higher or lower than profits in Europe. Profits in the US will be higher if the manufacturing sector's labor force and output are larger than Europe. More land and higher incomes mean a greater demand for manufactures, while a lower relative price of food implies

2 The treatment here follows Findlay (1995, Chapter 1).

3 Corden and Neary (1982) consider the impact of a Hicks-neutral technological improvement in one sector, and distinguish between the resource movement and spending effects of the associated boom. 
the opposite. The net impact of an increased land endowment on profits thus depends on the relative size of these income and substitution effects.

Thus, there are two possibilities. Either land and capital are cheaper in the US than in Europe (while labor is more expensive); or us land is cheap, while US capital and labor are expensive (the dual scarcity case). In the first case, Us capital should flow to Europe, while European labor should migrate to the Us; in the second, dual scarcity, case, there is an incentive for both labor and capital to flow from Europe to America.

What does a move from autarchy to free trade imply for these migration incentives? The US exports food, and the relative price of food in the us increases. This increases us rents, and lowers us profits; meanwhile, trade increases European profits, but lowers European rents. In the first case (land and capital cheaper in the Us) the incentive for Us capital to emigrate has increased. Thus, trade and factor mobility are complements. In the second case (cheap us land but expensive us capital), the incentive for European capital to emigrate has declined. In effect, trade and factor mobility are substitutes. As for labor, the impact of relative price changes on real wages is ambiguous: trade could be a substitute or a complement to migration.

The same ambiguity emerges where the impact of factor flows on trade is the issue. Labor migration's impact on trade is ambiguous because it depends on the migration's impact on relative outputs in Europe and the Us. Similarly, if capital is cheaper in the us than in Europe, then capital flows from America to Europe will increase trade llowering relative supplies of food in Europe, and increasing them in the US); but in the 'dual scarcity' case, capital flows to the Us will increase us manufacturing and diminish Us agriculture, lowering the volume of trade. This ambiguity has been rigorously demonstrated in a recent paper by Neary (1995).

clearly, the relationship between trade and factor mobility is ambiguous in the specific factors model. Indeed, from the above discussion it is clear that trade could be complementary to migration, but a substitute for capital flows, or vice versa. To take just one example from a range of possibilities, 
in the dual scarcity case, capital flows and trade are substitutes; this does not preclude the possibility that emigration would increase the supply of manufactures relative to food in Europe, and that immigration would increase the supply of food relative to manufactures in the US (in which case migration and trade are complements). Going from the specific factors model to a more general $3 \times 2$ model (in which land and capital are mobile between sectors) only increases the range of uncertainty. Thompson $(1985,1986)$, for example, has shown that price movements can have paradoxical effects on rents and profits.

\section{Frontier Arguments}

The existence of a third factor like land and other natural resources is not enough per se to generate a strong presumption of complementarity between trade and factor mobility. Such a presumption can emerge in the context of models where the effective supply of the third factor is endogenous -- a natural assumption in the context of late 19th century New World frontier economies or of labor-scarce Southeast Asian colonies. In particular, as food prices rise due to trade, there is an incentive to extend the frontier and to increase the effective supply of land. However, extending the frontier requires heavy capital inputs (e.g. Financing the railroads) and even labor (e.g. building the new towns). When the us opens to trade, and the relative price of food increases, the specific factors model may conclude that Us profits fall. In the dual scarcity case, this lessens the incentive for capital to flow from Europe. However, if the increase in the demand for capital associated with frontier extension is not completely offset by the decline in manufacturing's demand, then the return to capital in the US, and even the US-Europe profit differential, might increase. In this case, the incentive for capital to flow to the Us would also increase. Similarly, if extending the frontier sufficiently increased the Us demand for labor, this might create the presumption that US-Europe wage gaps would also increase. The existence of an endogenous frontier seems to increase the likelihood that trade and factor mobility will be complements, rather than substitutes. 
However, the elegant and simple models of an endogenous New World frontier which Findlay (1995) has constructed show that even in this case, trade and factor mobility can be substitutes.

Very stylized models of North-South trade can produce unambiguous complementarity. If the North exports manufactures and imports natural resources, and if northern investment in the south is required for the exploitation of the south's resources, then complementarity is assured. Such a model was outlined some time ago by Kemp and ohyama (1978), even though they were interested in a different set of issues. Schmitz and Helmberger (1970) argued strongly for complementarity between capital flows and trade, on the basig that capital inflows are required to develop the exports of extractive industries in LDCs. Williams (1929) also argued that capital mobility and trade in resources were complements rather than substitutes. This argument resembles the frontier argument just put forward: in both cases, there are surplus resources which require foreign investment before they can be vented onto world markets.

The complementary frontier argument can be extended to a Third world context too. City building is very capital-intensive, and to the extent that globalization generates an export boom of labor-intensive manufactures in the Third World, it also induces city growth (Kelley and williamson 1984; IBRD 1995). This, in turn, generates heavy social overhead demand, high returns to capital and foreign investment (Lewis 1978). Thus, trade and capital flows are complements, not substitutes.

Of course, this argument has its reverse. With the disappearance of 19th century frontiers, town bullding slowed down and railroad and other "population sensitive" investment dropped off, and this, in turn, may have caused international factor mobility to subside, complementarity to vanish, and substitutability to emerge. Iikewise, with the completion of 20 th century urban social overhead in the Third World, factor mobility may subside, complementary may vanish, and substitutability may emerge.

Three morals emerge from this survey of what standard theory has to say 
about the substitutability versus complementarity question. First, theory is ambiguous, as the Venables chapter confirms. The ambiguity can only be resolved with evidence, and history is certainly a good place to look for that evidence. Second, endogenous frontier models seem to offer a clear and historically relevant case where trade and factor mobility are more likely to be complements. To the extent that frontier settlement is a transition process, we should look to disequilibrium transitions for evidence of complementarity. A transition has ended when a frontier has disappeared or an economy is fully urbanized. Third, the 'correct' model will vary with the period being studied. Regime switches are likely to be common, especially at the beginning and the end of a transition.

With this brief survey of theory to guide us, we are ready to look at pre-World War II history. We start with macro instability and the long swing.

\section{Time Series: Macro Instability and the Iong Swing 1870-1940}

In 1968, Moses Abramovitz gave a University Lecture at the London School of Economics on "The Passing of the Kuznets Cycle", that special form of macro instability which characterized so much of the Atlantic economy prior to 1914. Abramovitz preferred to call these events Kuznets Cycles, after their discoverer (Kuznets 1930, 1958). But these 15-20 year growth surges and slowdowns were also called "long swings", and, unless interrupted by war, they typically ended in severe depressions: e.g., the mid-1870s, the mid-1890s, and the 1930s. Abramovitz and other scholars (Lewis and O'Leary 1955; Abramovitz 1961; Easterlin 1966, 1968) documented long swings in the rate of frontier settlement, accumulation, labor force growth, productivity advance, city building and other underlying fundamentals associated with long run growth.

These booms and busts were global in scope. Given that primary product markets always exhibit greater instability during global booms and busts, it is not surprising that the long swings were most dramatic in the resourceabundant New World. Nonetheless, they were also apparent in much of Europe 
where they generated waves of urbanization and industrial growth, typically producing old world long swings in domestic accumulation rates which moved inversely with those in the New world.

The global character of these long swings also manifested itself in factor flows, relative prices and, to some extent, trade. The pattern appeared in the rhythm of the mass migrations, which recorded spectacular flows from Europe to the New world during booms, and net return migration during busts (D. Thomas 1941; B. Thomas 1954; Easterlin 1961; Wilkinson 1967; Williamson 1974; Hatton and Williamson 1997). It also appeared as waves in net international capital movements, which recorded massive outflows from Germany, France and especially Britain during booms abroad (slumps at home) and a flight back home during slumps abroad (booms at home) (Cairncross 1953; Williamson 1964). It appeared in relative prices (Abramovitz 1961; Williamson 1964; Rostow 1978), and, for some primary product exports at least, in trade. Transport costs fell globally so every trading partner could have enjoyed an improved terms of trade prior to world war I. But around that trend, the New World terms of trade improved during New World booms, while it slumped in Europe. We have always thought that the growth in primary product exports from the New world surged and collapsed over these long swings, but in the long run commodity market globalization was achieved (Williamson 1996). Figures 1 through 4 illustrate these "long swings" for the two most important economies in the Atlantic community, the United states and the United Kingdom, where the epochs are broken up into the pre-war globalization phase 1870-1913 and the post-war de-globalization phase 1919-1936. These figures show clearly the enormous instability in the time series, that migration (mig) and capital flows ( $\underline{\text { l }} \mathrm{CA}$ ) are highly correlated (capital chases after labor), but that aggregate trade levels (lㅏrade) are, somewhat surprisingly, not well correlated with either.

Designing an empirical framework to capture the complementarity or substitutability of trade and factor flows is challenging, and the dearth of 
empirical investigations of this phenomenon must be due in large part to the seeming intractability of the problems at hand: issues of endogeneity, measurement, and interpretation are formidable obstacles. Undaunted, we pursued two means of measuring the association of trade volumes with factor flows in each country's time-series. First, we simply asked whether relatively large (small) factor flows are associated with relatively small (large) trade flows ceteris paribus, regardless of the direction of the factor flows. The focus in this first approach was on magnitudes alone, and the absolute values of factor flows were entered in the regressions. But with a given endowment, should a factor inflow and a factor outflow of the same magnitude be expected to have the same impact on trade volumes? It could be argued that if trade and factor flows are substitutes, then emigration (or capital exports) is expected to lessen trade only if labor (or capital) is leaving a relatively labor (or capital) abundant country. Our second approach incorporated a notion of factor scarcity and abundance based on measurements of land, labor and capital for each country in the sample. This approach asked whether factor flows in the "right" direction (into a factor scarce country or out of a factor abundant country) were associated with more or less trade. The determination of factor abundance/scarcity was based upon the country's share in the sample's total endowment of a given factor relative to the country's share in the sample's total GDP. ${ }^{4}$ since it turned out that these two approaches yielded much the same results, we only present the first in what follows.

Table la reports results when real trade values are regressed on absolute real values of factor flows (gross immigration or emigration mig and net capital flows as measured by the current account balance rlCA), plus

4 As the next section will show at greater length, this alternative approach relied on assumptions about which way factors "should" flow based on Heckscher-Ohlin-Vanek reasoning. Relative abundance or scarcity was determined by using endowment measures of labor, land and capital for each of the ten countries in combination with the country's share in the sample's total GDP. As the text indicates, this second approach yielded roughly the same results as those implied by Tables $1 \mathrm{a}$ through 1c, and thus are not reported here. 
additional variables to be discussed in a moment; Table lb reports results when first differences in trade values are regressed on first differences in factor flows; and Table $1 \mathrm{c}$ reports results when first differences in trade values are regressed on factor flows. The dependent trade variable is simply the deflated sum of exports and imports (rltrade). 5 All of the regressions use the Cochrane-orcutt procedure to account for serial correlation in the error terms. The results in Tables la through lc appear to be consistent. Furthermore, the results seem to be robust to many other specifications we tried. 6

The regressions were estimated with time and time squared (coefficients not reported in Tables la-1c) to isolate macro instability (e.g., long swings) from the trends in the country time series.

Tariff rates (thariff) were introduced to reflect the fact that many of these countries retreated from globalization in the late 19th century, and that all of these countries participated in the race towards de-globalization after WWI. 7 We expected negative coefficients here, and our expectations are confirmed (with the odd exception of Canada). We also introduced a crude measure for transport costs (Isserlis 1938) $i^{8}$ it almost always has the wrong sign in these long swing regressions probably because transport costs were endogenous to trade volumes over the long swing, rising during booms as space in tramp bottoms got scarce, and falling during slumps as space in tramp bottoms got abundant. We expect different signs on transport costs when these cycles and swings are removed from the data, and thus where exogenous supply-

5 Data sources are discussed in the appendix.

6 The same results emerged when trade shares in GDP were regressed on factor mobility rates. Furthermore, the same results emerged whether we estimated the regressions separately for $\mathrm{mig}$ and $\underline{\text { rlCA}}$, or together as in Tables la through $1 \mathrm{c}$ in the text.

7 The tariff rate measure is crude, customs revenues relative to imports, but it should be effective enough over a long swing in the time series.

8 It is, appropriately, a deflated freight rate index, but it is a generic world wide index rather than a country-specific index. 
side forces are more likely to dominate.

The impact of the frontier and/or policy change is explored by estimating separately relationships for the pre-war years (1870-1913) and for the inter-war years (1919-1936). Our expectation was that complementarity would appear more frequently in the pre-war decades than afterwards, especially for the resource-abundant New world.

Most important for the purposes of this study are the factor flow variables. Migration measures gross intercontinental emigration from the European countries and gross immigration to the New world countries (except for Australia which reports net in-migration). The current account variable is the overall current balance, deflated by a GDP deflator for the sake of intertemporal comparability. True, no respectable economic historian could possibly hold the view that mass migration (Hatton and Williamson 1997) and international capital flows (Zevin 1992; Taylor 1996) were exogenous, and to the extent that endogeneity exists (for example, as a feedback from trade to the factor flows) the estimated coefficients on the factor flow variables will be confounded. Yet, it is far easier to make that assertive statement than to construct instrumental variables annually to deal with endogeneity. In any case, we are not arguing that the regressions identify the causal mechanism running from factor mobility to trade. Rather, we are only exploring correlations, and Tables la through lc are titled accordingly.

With these caveats firmly in mind, we next explore those results most relevant to the central question, namely: what are the coefficients on the factor mobility variables? Tables $2 \mathrm{a}$ through $2 \mathrm{c}$ summarize the results in terms of the hypothesis being tested: complements or substitutes? Deriving any Table 2 from the relevant Table 1 is straightforward: a positive and significant coefficient is interpreted as complementarity, a negative and significant coefficient is interpreted as substitutability, and any 
coefficient not statistically different from zero is deemed neutra1.9

Neutral entries dominate all three tables $(53,78$ and 68 percent in Tables $2 \mathrm{a}, 2 \mathrm{~b}$ and $2 \mathrm{c}$ respectively, or 66 percent overall), suggesting that the theoretical ambiguities highlighted in the previous section find their match in empirical ambiguities. Nevertheless, complementarity is far more common than substitutability, and it accounts for 26 percent of the entries in all three tables combined. In addition, complementarity is associated almost twice as often with migration (34 percent), than with capital flows (19 percent). Substitutability appears in only 8 percent of the cases, and all but one of those cases involves capital flows, not migration. This distinction between capital flows and migration suggests that some factor flows are more closely related to trade than others.

So far, history soundly rejects substitutability. However, there are two unpleasant surprises that also appear in Tables $2 \mathrm{a}$ through $2 \mathrm{c}$. First, and contrary to prediction, complementarity was not more pervasive in the resource-abundant New World (19 percent in all three tables combined) than in the resource-scarce old World (29 percent in all three tables combined). second, and again contrary to prediction, complementarity was three times more common in the "post-frontier" period: complementarity occured 36 percent of the time during 1919-1936 but only 12 percent of the time during 1870-1913.

Our priors strongly suggested complementarity and regime switch away from complementarity and towards substitutability. Much to our surprise, the evidence rejects the latter in the sense that it supports a regime switch towards complementarity, when the "disappearing frontier" thesis predicted a regime switch from complementarity. Perhaps the complementarity is actually driven by policy, the simultaneous breakdown of international commodity and factor markets. And although there is some evidence to support

9 Tables $2 \mathrm{a}$ through $2 \mathrm{c}$ use a 10 percent level in the hypothesis testing, but the same qualitative results emerge when a 5 percent level is used. The only difference is that in the latter case some complementarity results fall in to the neutral category. In short, the substitutability hypothesis is still soundly defeated. 
complementarity, we expected stronger and more comprehensive confirmation given the plausible inferences emerging from the newer endogenous frontier models and the older long swing literature. Another blow to any endogenous frontier model favoring complementarity is the finding that the New world with the frontier offers no evidence of stronger complementarity than the old World without the frontier. In any case, the long swing evidence certainly rejects substitutability.

\section{Panel Data from History: The Atlantic Community 1870-1940}

This section takes another step towards filling the empirical void in the substitutability versus complementarity debate by exploring long-run relationships in panel data for the Atlantic community (plus Australia) between 1870 and $1940 . .^{10}$ Trade volume is now measured as the sum of imports and exports relative to GDP (as opposed to the previous section which measured "real" trade levels for each country). One important advantage of this new trade volume measure is that it provides a simple metric for comparison across countries which does not require the difficult translation of each country's trade into a common (real) currency via exchange rates and import and export price indices. One potential disadvantage of the new measure, however, is that it departs from Heckscher-ohlin-Vanek theory which relates the volume of a country's trade, unscaled by GDP, to the gap between its factor endowment and its factor consumption. Nevertheless, an effort will be made to develop a measure of the distance between endowment and factor consumption points which includes the necessary scaling. In particular, three endowments are measured for each of the ten countries: population, arable land, and capital stock proxied by coal consumption. ${ }^{11}$ The calculation of distance, $D$, through three

10 As in the previous section's long-swing analysis, the sample includes Australia, Canada, Denmark, France, Germany, Italy, Norway, Sweden, the UK, and the Us.

11 See Estevedeordal (1993, p.20) or Landes (1969, p. 293) for examples and justifications of this proxy. 
dimensional space is complicated by the different units of measurement along each of the three endowment axes, and so all units are converted to proportions of the sample total. Distance is calculated as follows:

$\mathrm{D}_{i}^{2}=\left(\mathrm{Pop}_{i} / \text { Pop }_{w}-\gamma_{i}\right)^{2}+\left(\text { Land }_{i} / \text { Land }_{w}-\gamma_{j}\right)^{2}+\left(\mathrm{K}_{i} / \mathrm{K}_{w}-\gamma_{j}\right)^{2}$,

where $i$ denotes a particular country, w denotes the sample total, and $\gamma_{j}$ represents $\operatorname{GDP}_{\mathfrak{j}} / \mathrm{GDP}_{\mathbf{w}}$. If the dependent variable in the panel were simply total trade (unscaled) in a constant and common currency, then we would use D (unscaled) to help explain the volume of trade. But because the dependent variable is trade/GDP, we scale D by $\gamma \cdot{ }^{12}$ For a given gap between the factor consumption and endowment points, a simple substitutable relationship between factor flows and commodity trade would suggest that larger factor flows would be associated with smaller commodity flows.

A higher level of tariffs is expected to decrease the volume of trade, and this expectation was confirmed over long swings in the previous section. We have only a rough guide to tariff levels: (customs revenue)/imports. But depending on the mix of tariffs, quotas, and prohibitions, this measure can still serve as a useful proxy for protection over time and across countries. It is well known that transport costs declined substantially over the full course of this period, and the Isserlis index of these costs is included in the regressions. However, since the index number is identical for each country, it can only be useful, potentially at least, in explaining variation in trade/GDP over time.

The explanatory variables of greatest interest to this paper are average annual net migration rates and the current account relative to GDP for each decade between 1870 and 1940. With three exceptions, the migration rate used

12 If country $A$ has endowment vector $V$ and country $B$ has endowment vector $2 \mathrm{~V}$, we would expect $B$ to have a larger (unscaled) volume of trade and a larger measure of $\mathrm{D}$, but the countries should have the same amount of trade/GDP and we would want them to have the same measure of $D / \gamma$, ceteris paribus. 
in this section is a net rate calculated using the following method: ${ }^{13} \mathrm{first}$, the period's average rate of natural increase is applied to the population at the period's beginning which provides an estimate of the population at the end of the period if no one has emigrated or immigrated; second, the actual endof-period population is subtracted from the counterfactual end-of-period population to provide an estimate of net migration over the period. This is expressed as an annual rate per thousand population in the base year.

Table 3 pursues a simple question: ceteris paribus, do larger flows of people and capital tend to be associated with higher or lower volumes of trade? ${ }^{14}$ The table reports several specifications of the same basic regression equation, where Endow is the distance between the endowment point and consumption point in three-dimensional space calculated as described above. The basic regression is specified as follows:

$$
\begin{aligned}
& (\text { Trade } / G D P)_{i t}=\alpha+\beta 1 * \text { Emig. Rate } i t+\beta 2 *(C A / G D P)_{i t}+\beta 3 * \text { Tariff }_{i t}+ \\
& +\beta 4 * \text { Transport }_{t}+\beta 5^{* \text { Endow }_{i t}} \varepsilon_{i t} \text {. }
\end{aligned}
$$

A formidable challenge for such a simple empirical strategy is to account for the endogeneity of the factor flow variables. Certainly, the relationship between factor flows and trade is not a one-way street, and this must be kept in mind when interpreting the coefficient estimates of $\beta 1$ and $\beta 2$. An instrumental variables approach could be useful in meeting this challenge,

13 Italian emigration is taken from Bacci (1978, p. 39). The US rate is taken from Eldridge and Thomas (1964). The Australian rate is calculated using net immigration figures from Mitchell (1983). We calculated net migration rates for the other seven countries using the method described in the text.

14 A previous version of this paper took account of the direction of factor flows, rather than focusing on size exclusively. Each country in each time period was designated abundant in a factor if its share in the total sample's endowment exceeded its share in the total sample's GDP. Abundant countries are expected to export that factor to close the gap between its endowment point and its factor consumption point (assumed to be along the diagonal of the world factor "box"). Observing the direction of actual factor flows, we then asked whether factor flows in the "right" direction decreased trade flows, as a substitutable relationship would suggest. 
although it is extremely difficult to identify truly exogenous variables that are correlated with the factor flows but not affected in turn by the volume of trade or by omitted variables which might af fect both trade and factor mobility. ${ }^{15}$

The first column of Table 3 reports regression results from simply pooling all of the available decade-averaged observations $(\mathrm{N}=58)$. The measure of tariffs enters strongly negative, as expected, and the measure of the endowment point's distance from the assumed factor consumption point enters positively and surpasses the ten percent significance level. The transport cost variable has no discernable correlation with trade/GDP. Both the current account variable and the emigration rate are statistically insignificant in the pooled sample. Very similar results are attained in column two when using fixed effects by period, thus relying on variation across countries, to estimate the coefficients. This fact suggests that variation across countries dominates variation over time in determining the pooled regression results.

Using the panel in column three to carry out fixed effects estimation by country, however, provides a view of the data that is more compatible with the long swing analysis in the previous section. The tariff coefficient is still statistically significant and negative, but it is less than half the size of the coefficient estimated in the pooled regression. The endowment distance variable enters positively at approximately the same size as in the first two columns, but it is far from statistically significant. The current account variable is positive and statistically significant, whereas the migration rate is negatively (but not significantly) associated with the level of trade/GDP. Employing a full set of country and period dummies yields the fourth column's results which again find a negative correlation between trade/GDP and labor

15 The previous version of this paper attempted to use the lagged rate of natural increase and a New World dummy variable to instrument for the emigration rate, and used the dependency rate (proportion of population under age fifteen) to instrument for the current account balance (Taylor and williamson 1994). The current framework, which employs the absolute value of factor flow measures, is not well-suited for these instruments. Moreover, such instruments are far from exogenous. 
flows, but a positive relationship between trade/GDP and capital flows.

Even in the third and fourth columns, where the factor flow variables receive their largest coefficient estimates, the coefficients imply a weak economic link between factor flows and trade flows. A one standard deviation increase in the absolute value of the emigration rate (3.46) decreases trade/GDP by only 0.009 according to column three. A one standard deviation increase in the absolute value of the current account/GDP (0.020) increases trade/GDP by only 0.023 according to column three. These magnitudes appear to be small relative to the average trade/GDP share $(0.34)$.

Like the long swing analysis in the previous section, the panel data provide virtually no support for the substitutability hypothesis. The panel data do provide some limited support (once country dummies are included) for complementarity between capital flows and trade. Even when significant, however, the size of all the estimated coefficients indicate a weak economic link between factor and trade flows. ${ }^{16}$

\section{Political Economy Connections: Tariffs and Immigration Restrictions ${ }^{17}$}

International trade takes pride in emphasizing the endogeneity of many variables. In that spirit, this section reports an effort to endogenize New World immigration policy. Did New World immigration policy behave in a fashion which suggests that the decision-makers of that time viewed trade and factor flows as substitutes?

The Stylized Policy Facts

After the 1880s, there was a gradual closing of New World doors to immigrants. The doors did not suddenly slam shut on American immigrants with the Congressional override of President Wilson's veto of the immigrant

16 This finding is echoed in the empirical literature on trade, foreign domestic investment and multinational corporations (Grubert and Mutti 1991).

17 This section draws heavily on Timmer and williamson (1996). 
literacy test in February 1917 or by the Emergency Quota Act of May 1921. The United States started imposing restrictions on what had been free immigration not too long after the Civil War, a half-century prior to the Literacy Act. Furthermore, the United States was hardly alone. Australia, Argentina, Brazil and Canada did the same, although the timing was often different and it often took the form of an enormous drop in or even disappearance of what had been large immigrant subsidies rather than of outright exclusion. In short, there was considerable variance in immigration policy across these five New World countries over the half century. It was not simply one big policy switch around World War I.

And what was true of immigration policy was also true of trade policy. Globalization proceeded in fits and starts in the three decades after 1846 when Britain repealed the Corn Laws and started a liberal trend towards free trade on the Continent. Add to that enormous declines in international transport costs, and you have the ingredients for the first great globalization boom. As we have seen, it took the form of a trade boom, mass migrations, and international capital flows at levels never reached before or since. The liberal trend did not last long, however, and there was a globalization backlash. Tariffs started to rise on the European Continent, while immigration and trade restrictions started to rise in the New World. With the end of World War I, the world economy plunged into a dark age of deglobalization and hostile policy towards open factor and goods markets. This long interwar period of darkness was followed by a liberal renaissance embedded in Bretton Woods, GATT, guest worker arrangements in Europe, the 1965 repeal of national origins quotas in the US, foreign capital market deregulation and other policy events consistent with globalization, especially after the early 1970s.

What explains changing immigration, tariff and external capital market policy, and how are they related? For world globalization to persist, rich nations must play the liberal game. After all, typically they have the big markets. Poor nations, in turn, are dependent on those big markets to sell 
their labor-intensive exports, to secure finance for projects in their capital-scarce economies, and to vent their surplus labor on rich countries willing to absorb unskilled immigrants. The problem for rich countries is that globalization can reduce high real wages there, or at least produce inequality.

So, what determined trade and immigration policy in the rich, laborscarce nations in the late 19th century when there was still a frontier? Did these nations pursue legislation then which suggests that politicians and voters believed that trade and immigration were substitutes? If they thought so, then they would have believed that it was no use restricting just one when workers' living standards were under threat, but rather that they had to restrict both. Alternatively, if trade and factor flows were complements, then restricting either trade or immigration would have done the trick. The US was indeed protectionist, especially after the Civil war when landed and slave interests in the South had been defeated. And Canada was protectionist, especially after 1878. The fact that both countries gradually moved to restrict immigration is consistent with our earlier suggestion that, as the frontier closed, trade and factor flows moved from being complements to being substitutes. However, the closing of the frontier might have mattered more directly for the immigration debate.

Americans thought the western frontier had disappeared in the 1890s, Argentinians thought the Pampas had filled up shortly thereafter, Brazilians in sao Paulo must have thought the same as coffee prices collapsed in the 1920s, and Canadians must have shared this view when declining grain prices brought an end to their prairie boom. simple theory would predict that the closing of the frontier had an impact on attitudes towards immigration: the wage impact of immigration should have been lower when elastic supplies of land were available, since they could absorb new workers. The timing of new world immigration restrictions seems roughly consistent with this view.

Is the timing of immigration restriction adequately explained by the less elastic New World demand for labor implied by closing frontiers? or did 
a changing relationship between trade and factor flows -- first complements, then substitutes -- also play a role? Were immigration restrictions positively associated with tariffs, as would be true if trade and factor flows were substitutes, and did the association between tariffs and migration policy change over time?

More generally, what explains immigration restriction itself? The answer ought to be consistent with the correlations invoked elsewhere in this paper, but three candidates dominate all others -- rising inequality, greater awareness of that inequality by the politically powerful, and greater voting power in the hands of those hurt most by liberal policy -- the working poor.

Surprisingly, there have been few attempts to introduce these long run fundamentals into explicit models of immigration policy, although there have been many attempts to make trade policy endogenous. Furthermore, we are aware of only three efforts to test immigration policy models with historical evidence (Shughart, Tollison and Kimenyi 1986; Foreman-Peck 1992; Goldin 1994). Two recent papers by Ashley Timmer and one of the present authors (Timmer and Williamson 1996, 1997) add to this new literature. The next section will summarize their results, but only to the extent that the complements-versus-substitutes issue can be placed in proper perspective.

\section{Policy Complements or Substitutes? An Empirical Test}

Unskilled labor at the bottom of the distribution is scarce and expensive in rich countries, and that fact by itself should make income distributions more egalitarian than in poor countries. Immigration, especially low quality immigration from poor countries, should erode unskilled labor scarcity in rich countries and raise inequality. Labor-intensive commodity imports should do the same. How should policy respond? If, driven by the presence of a frontier, trade and immigration were complements in the pre-World War I rich New World, protection and immigration restriction need not have gone hand in hand. Such a correlation might have emerged as the frontier disappeared. 
Among the many results reported by Timmer and Williamson (1996), Table 4 presents just one which captures the central issue in this paper. The underlying panel data are for five countries -- Argentina, Australia, Brazil, Canada and the United States, from about 1860 to 1930, and where the unit of observation is a half-decade. The dependent variable measures the extent to which policy is pro-immigration (POLICY): the index varies from -5 to +5 , the former reflecting severe anti-immigration restriction, including discrimination in labor markets, the latter reflecting strong pro-immigration, including large subsidies, while 0 reflects neutrality. The econometric estimation uses fixed effects, with the lagged dependent variable on the right-hand side.

Four variables matter most. First, policies persist: the lagged dependent variable is large and significant. However, politicians were not total prisoners of the recent political past, since the coefficient on the lagged dependent variable is 0.8 , not one. Second, the lagged relative position of the unskilled at the bottom of the distribution mattered. The numerator in the wage-to-GDP-per-worker ratio is the unskilled wage, so the ratio measures the economic distance between the bottom and the average. When the unskilled were relatively scarce (w/y was high), PoLICY was more liberal towards immigration. When the unskilled were relatively abundant (w/y was low), New World POLICY was relatively restrictive. Third, a lagged rise in an immigrant threat to unskilled workers' wages tended to generate more restrictive policy (the coefficient on lagged THREAT is negative), where THREAT is the combined influence of the immigration rate and the inverse of immigrant quality. Fourth, the quality of the immigrants relative to natives (and previous immigrants) mattered with a lag. IMWAGE is calculated as the wage difference between receiving and sending countries, and the bigger the "quality difference", the more restrictive the immigration policy.

The remaining right-hand side variables are insignificant, so we will not discuss them here, except for one: the ratio of trade to GDP ([X+M]/Y). 
Any economist who has explored trade policy knows how difficult it is to construct a satisfying summary statistic of "protection" and "openness" (Anderson and Neary 1994; Sachs and Warner 1995; O'Rourke and williamson 1997; O'Rourke 1997). We confess that the openness measure used here, $[X+M] / Y$, is a crude index of trade policy. Nonetheless, there is no evidence of a significant positive correlation between trade and immigration policy. Between 1860 and 1930, policy did not behave as if New World politicians and voters thought trade and immigration were substitutes.

\section{History's Bottom Line}

The elegant model associated with Eli Heckscher and Bertil ohlin makes the unambiguous statement that trade and factor mobility are substitutes. In the absence of factor mobility, trade can serve as an indirect substitute. In the presence of factor mobility, trade is no longer necessary. The issue is important for the policy implications it generates. If immigration threatens egalitarian distributions by creating labor abundance at the bottom of the distribution, immigration quotas will simply provoke more trade and a flood of "unfair competition" from unskilled workers making labor-intensive goods in distant lands of labor surplus from which they can no longer emigrate. If rich countries retreat behind tariff walls, there will be far more immigrants hammering at their gates since opportunities for making labor-intensive export goods at home have dried up. The economics is so plausible, that it survived with little challenge over the four decades from the early post-World War I years, when Heckscher and Ohlin were writing, to 1957 when Robert Mundell published his seminal piece. In the four decades since, the challenges to that conventional wisdom have been so many that nothing but theoretical ambiguity remains.

The ambiguity invites empirical analysis. It is all the more surprising, therefore, that there has been so little econometric work on the question. This paper has started to fill the vacuum by exploring the 
historical experience of the Atlantic economy between 1870 and 1940 .

The historical bottom line is this: When we look at the long swings embedded in the time-series data, we find that trade and capital flows were rarely substitutes and often complements. The same was true for trade and migration. When we look at longer-run relationships in the panel data, we find once again that trade and capital flows were rarely substitutes and often complements. Trade and migration were never substitutes. When we look at immigration policy in the New World, it appears that policy makers never acted as if they viewed trade and migration as substitutes either.

The history of the Atlantic economy between 1870 and 1940 rejects the thesis that trade and factor mobility were substitutes. It is a little more comfortable with the thesis that they were complements. Whether the same is true of the late 20 th century is another matter entirely, but we have attempted to show a way to discriminate between the propositions. 
Figure 1: Long Swings in Trade and Factor Flows

United States, 1872 to 1913

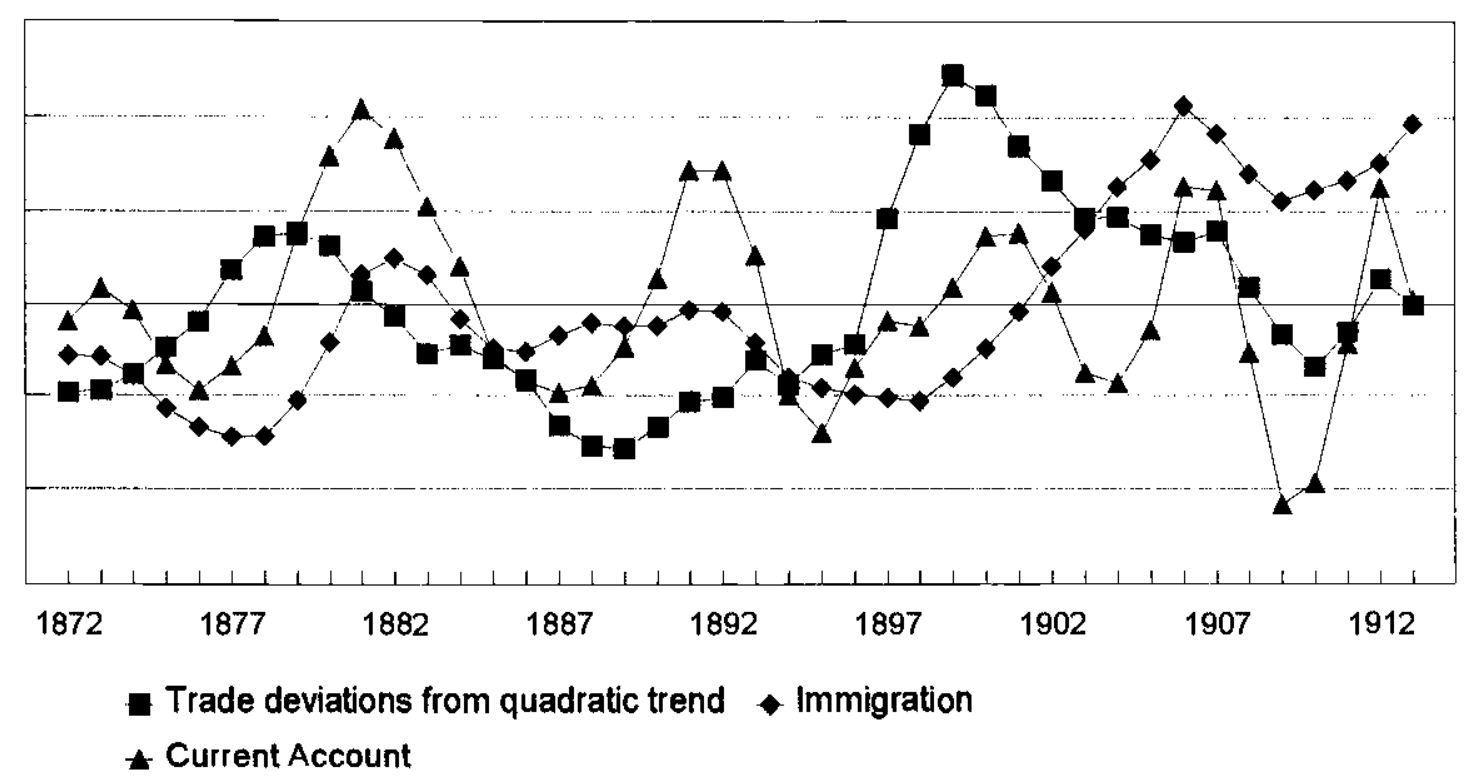

All series are three year moving averages and rescaled for presentation. 
Figure 2: Long Swings in Trade and Factor Flows United States, 1920 to 1939

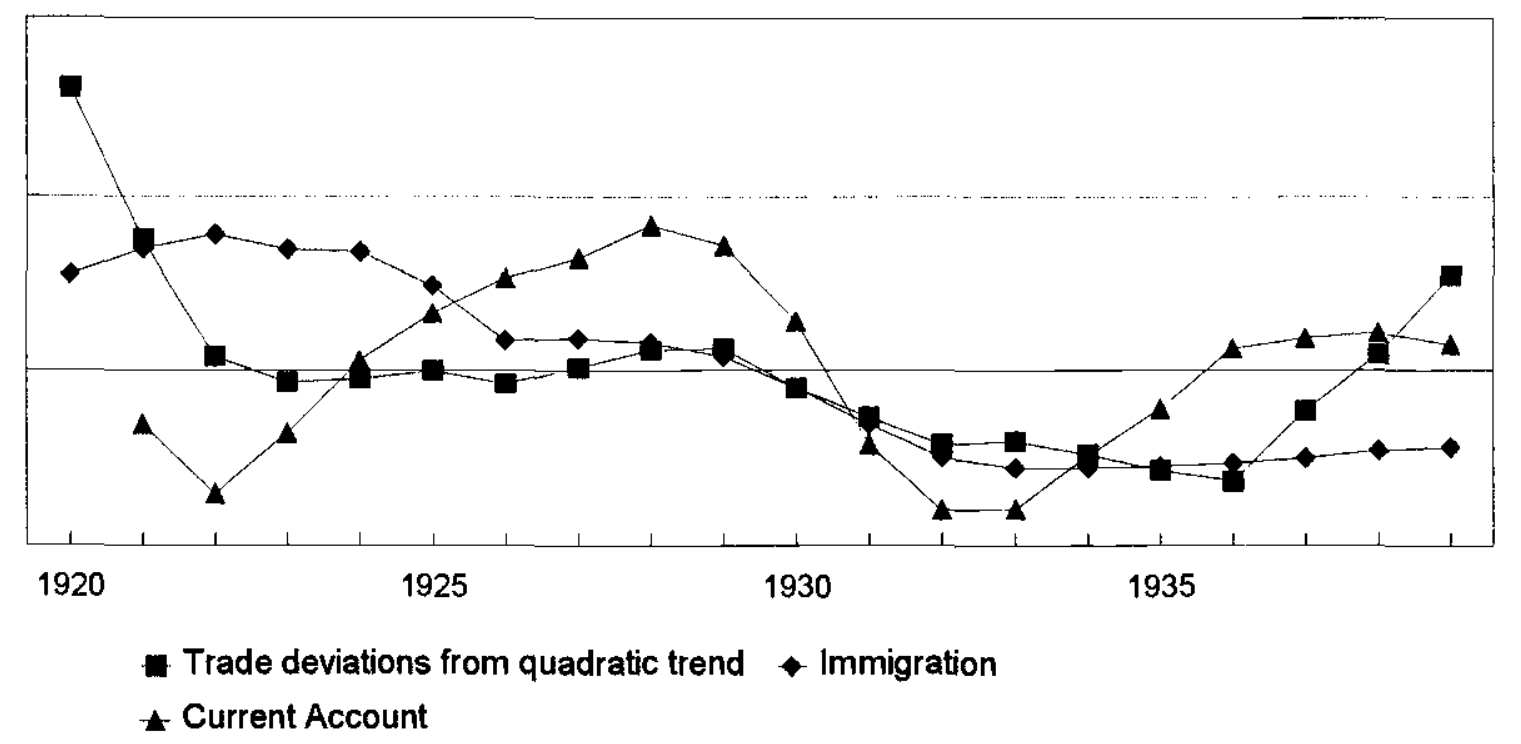

All series are three year moving averages and rescaled for presentation. 


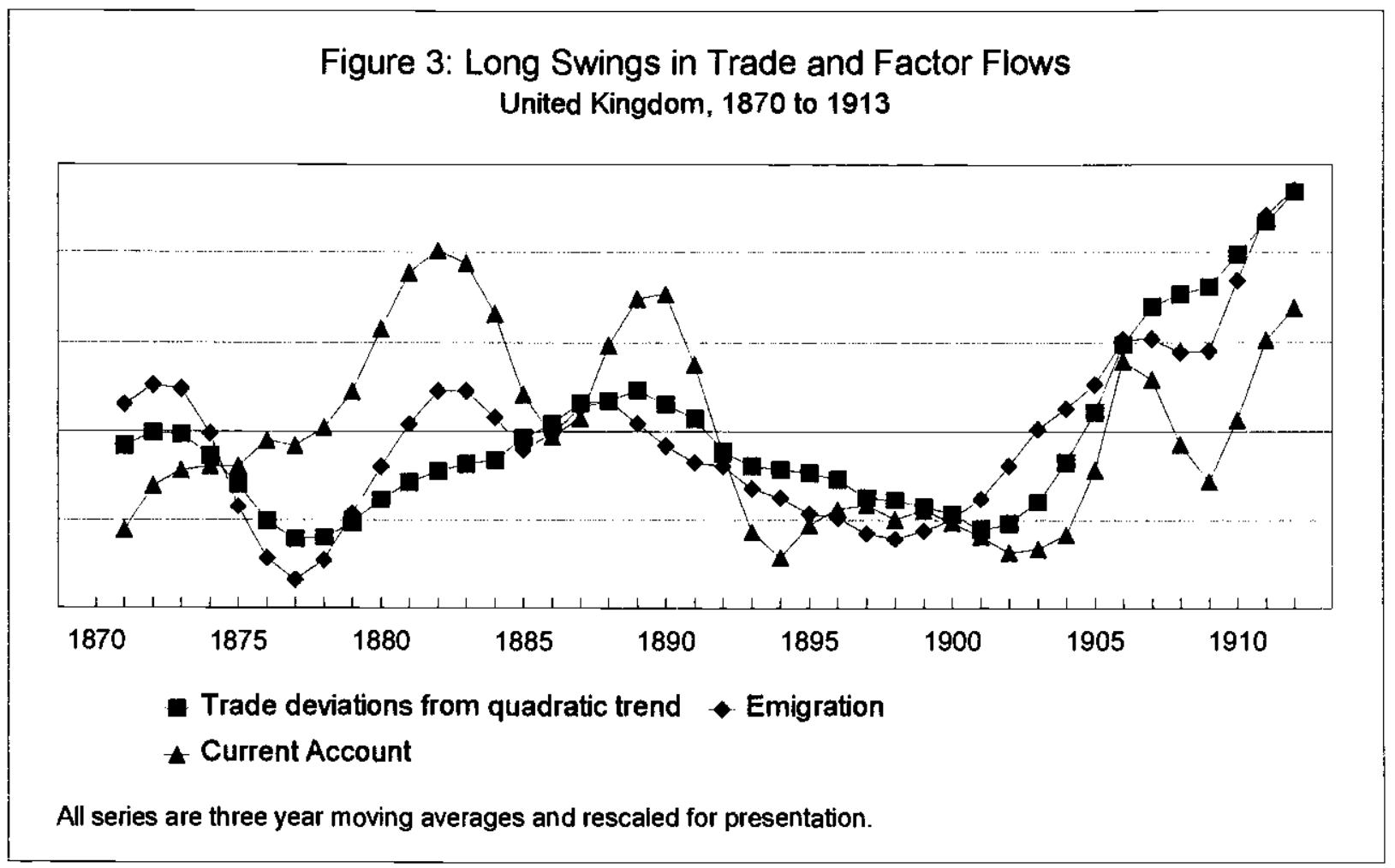


Figure 4: Long Swings in Trade and Factor Flows United Kingdom, 1920 to 1937

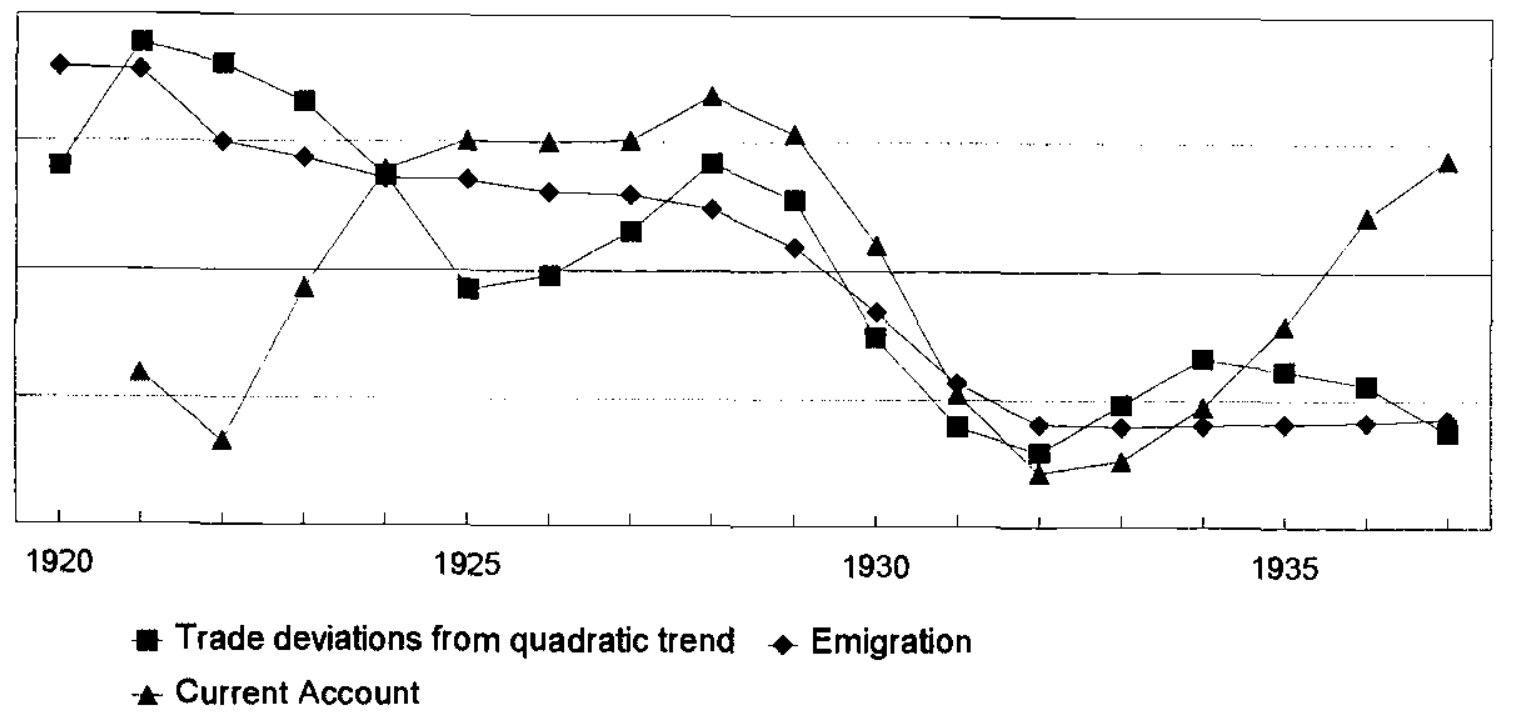

All series are three year moving averages and rescaled for presentation. 
Table 1a: Factor Mobility Correlates with Trade, 1870 to 1913 and 1919 to 1936

Dependent Variable: rltrade; Factor Mobility Variables: abmig, abrlCA

\begin{tabular}{|c|c|c|c|c|c|c|}
\hline & Migration & Curr.Act. & Tran.Cost & Tariff & $\mathrm{N}$ & $\mathrm{R}^{2}$ \\
\hline AUS: $1870-1913$ & $\begin{array}{l}0.169 \\
(3.11)\end{array}$ & $\begin{array}{l}-0.584 \\
(2.49)\end{array}$ & $\begin{array}{l}-0.021 \\
(0.14)\end{array}$ & $\begin{array}{l}-162.6 \\
(1.97)\end{array}$ & 32 & 0.95 \\
\hline AUS: $1919-1936$ & $\begin{array}{l}0.681 \\
(2.24)\end{array}$ & $\begin{array}{l}-1.06 \\
(2.38)\end{array}$ & $\begin{array}{l}-0.274 \\
(0.66)\end{array}$ & $\begin{array}{l}-271.9 \\
(3.12)\end{array}$ & 15 & 0.78 \\
\hline CAN: $1870-1913$ & $\begin{array}{l}0.810 \\
(1.18)\end{array}$ & $\begin{array}{l}-0.219 \\
(0.53)\end{array}$ & $\begin{array}{c}2.11 \\
(0.51)\end{array}$ & $\begin{array}{l}10812 \\
(1.52)\end{array}$ & 13 & 0.96 \\
\hline CAN: 1919-1936 & $\begin{array}{l}0.121 \\
(0.02)\end{array}$ & $\begin{array}{l}-0.075 \\
(0.05)\end{array}$ & $\begin{array}{l}32.11 \\
(1.13)\end{array}$ & $\begin{array}{c}4649 \\
(0.25)\end{array}$ & 17 & 0.22 \\
\hline USA: $1870-1913$ & $\begin{array}{l}0.882 \\
(4.29)\end{array}$ & $\begin{array}{l}0.063 \\
(0.31)\end{array}$ & $\begin{array}{c}5.01 \\
(1.07)\end{array}$ & $\begin{array}{l}-2530 \\
(1.53)\end{array}$ & 42 & 0.95 \\
\hline USA: $1919-1936$ & $\begin{array}{l}-2.73 \\
(1.18)\end{array}$ & $\begin{array}{c}3.70 \\
(2.84)\end{array}$ & $\begin{array}{l}68.07 \\
(1.33)\end{array}$ & $\begin{array}{l}-26639 \\
(2.33)\end{array}$ & 17 & 0.65 \\
\hline DEN: $1870-1913$ & $\begin{array}{c}1.37 \\
(0.31)\end{array}$ & $\begin{array}{l}0.263 \\
(1.09)\end{array}$ & $\begin{array}{c}1.08 \\
(1.00)\end{array}$ & $\begin{array}{l}-1515 \\
(1.60)\end{array}$ & 37 & 0.68 \\
\hline DEN: 1919-1936 & $\begin{array}{l}18.94 \\
(1.09)\end{array}$ & $\begin{array}{c}3.17 \\
(2.60)\end{array}$ & $\begin{array}{c}9.79 \\
(1.32)\end{array}$ & $\begin{array}{c}-43684 \\
(3.66)\end{array}$ & 13 & 0.79 \\
\hline FRA: $1870-1913$ & $-\cdots--$ & $\begin{array}{c}0.153 \\
(0.94)\end{array}$ & $\begin{array}{c}7.04 \\
(0.87)\end{array}$ & $\begin{array}{l}-31405 \\
(3.55)\end{array}$ & 43 & 0.72 \\
\hline FRA: 1919-1936 & ---- & $\begin{array}{l}-0.501 \\
(0.49)\end{array}$ & $\begin{array}{l}-150.2 \\
(2.23)\end{array}$ & $\begin{array}{c}-68824 \\
(5.18)\end{array}$ & 16 & 0.88 \\
\hline GER: $1870-1913$ & $\begin{array}{c}3.39 \\
(0.90)\end{array}$ & $\begin{array}{l}-0.511 \\
(1.56)\end{array}$ & $\begin{array}{l}20.01 \\
(1.78)\end{array}$ & $\begin{array}{c}-16617 \\
(0.97)\end{array}$ & 33 & 0.61 \\
\hline GER: 1919-1936 & $\begin{array}{l}115.4 \\
(8.95)\end{array}$ & $\begin{array}{c}1.40 \\
(5.97)\end{array}$ & $\begin{array}{l}175.62 \\
(7.09)\end{array}$ & $\begin{array}{l}-85107 \\
(45.21)\end{array}$ & 10 & 0.99 \\
\hline ITA: $1870-1913$ & $\begin{array}{c}5.93 \\
(2.02)\end{array}$ & $\begin{array}{l}-0.580 \\
(2.29)\end{array}$ & $\begin{array}{l}-4.02 \\
(0.15)\end{array}$ & $\begin{array}{c}-58523 \\
(7.92)\end{array}$ & 43 & 0.94 \\
\hline ITA: 1919-1936 & $\begin{array}{l}11.78 \\
(1.97)\end{array}$ & $\begin{array}{c}1.68 \\
(3.19)\end{array}$ & $\begin{array}{l}71.63 \\
(1.51)\end{array}$ & $\begin{array}{c}-51277 \\
(2.06)\end{array}$ & 17 & 0.84 \\
\hline NOR: $1870-1913$ & $\begin{array}{l}0.0001 \\
(0.14)\end{array}$ & $\begin{array}{l}-0.193 \\
(0.71)\end{array}$ & $\begin{array}{c}-0.0377 \\
(0.06)\end{array}$ & $\begin{array}{l}-759.3 \\
(2.18)\end{array}$ & 29 & 0.59 \\
\hline NOR: 1919-1936 & $\begin{array}{r}0.0071 \\
(1.10)\end{array}$ & $\begin{array}{l}-1.69 \\
(2.59)\end{array}$ & $\begin{array}{c}4.18 \\
(3.54)\end{array}$ & $\begin{array}{l}-4892 \\
(3.08)\end{array}$ & 17 & 0.67 \\
\hline SWE: $1870-1913$ & $\begin{array}{l}0.874 \\
(0.91)\end{array}$ & $\begin{array}{l}0.337 \\
(1.05)\end{array}$ & $\begin{array}{c}2.85 \\
(2.50)\end{array}$ & $\begin{array}{l}-3017 \\
(2.41)\end{array}$ & 43 & 0.88 \\
\hline SWE: 1919-1936 & $\begin{array}{l}41.48 \\
(1.84)\end{array}$ & $\begin{array}{c}1.84 \\
(2.14)\end{array}$ & $\begin{array}{l}-1.33 \\
(0.17)\end{array}$ & $\begin{array}{c}-12551 \\
(2.68)\end{array}$ & 15 & 0.80 \\
\hline UK:1870-1913 & $\begin{array}{l}0.427 \\
(4.38)\end{array}$ & $\begin{array}{c}-0.0001 \\
(0.00)\end{array}$ & $\begin{array}{l}-0.262 \\
(0.44)\end{array}$ & $\begin{array}{l}-3703 \\
(3.03)\end{array}$ & 43 & 0.94 \\
\hline UK: 1919-1936 & $\begin{array}{c}3.34 \\
(4.12)\end{array}$ & $\begin{array}{l}0.803 \\
(1.04)\end{array}$ & $\begin{array}{l}-5.72 \\
(2.17)\end{array}$ & $\begin{array}{l}-1934 \\
(3.26)\end{array}$ & 17 & 0.90 \\
\hline
\end{tabular}


Notes: The dependent variable (rltrade) is the deflated sum of imports and exports. The migration variable (abmig) measures the absolute value of gross immigration for New World countries (except Australia which reports net immigration) or gross intercontinental emigration for Old World countries. Adequate migration data are not available for France. The current account variable (abrlCA) measures the absolute value of the deflated overall current balance. The transport cost measure is the same for all countries. The tariff measure is customs revenue divided by import values. Time and time squared terms are not reported in the table. All regressions are Cochrane-Orcutt. t-statistics are in parentheses. 
Table 1b: Factor Mobility Correlates witl Trade, 1870 to 1913 and 1919 to 1936

Dependent Variable: Change in rltrade; Factor Mobility Variables: Change in abmig, abrlCA

\begin{tabular}{|c|c|c|c|c|c|c|}
\hline & Migration & Curr.Act. & Tran.Cost & Tariff & $\mathrm{N}$ & $\mathrm{R}^{2}$ \\
\hline AUS: 1870-1913 & $\begin{array}{l}0.111 \\
(1.22)\end{array}$ & $\begin{array}{c}-0.0636 \\
(0.20)\end{array}$ & $\begin{array}{l}0.0238 \\
(0.12)\end{array}$ & $\begin{array}{c}-152.46 \\
(1.52)\end{array}$ & 29 & 0.24 \\
\hline AUS: 1919-1936 & $\begin{array}{c}-0.0877 \\
(0.20)\end{array}$ & $\begin{array}{l}-0.383 \\
(0.93)\end{array}$ & $\begin{array}{l}-0.222 \\
(0.58)\end{array}$ & $\begin{array}{c}-110.47 \\
(1.42)\end{array}$ & 14 & 0.30 \\
\hline CAN: 1870-1913 & $\begin{array}{l}0.499 \\
(0.58)\end{array}$ & $\begin{array}{l}-0.205 \\
(0.38)\end{array}$ & $\begin{array}{l}-0.267 \\
(0.04)\end{array}$ & $\begin{array}{c}4507 \\
(0.44)\end{array}$ & 12 & 0.12 \\
\hline CAN: 1919-1936 & $\begin{array}{c}3.04 \\
(0.37)\end{array}$ & $\begin{array}{l}-0.691 \\
(0.52)\end{array}$ & $\begin{array}{l}30.40 \\
(1.39)\end{array}$ & $\begin{array}{c}-14819 \\
(0.82)\end{array}$ & 17 & 0.22 \\
\hline USA: $1870-1913$ & $\begin{array}{l}0.894 \\
(4.02)\end{array}$ & $\begin{array}{c}-0.0070 \\
(0.04)\end{array}$ & $\begin{array}{l}0.317 \\
(0.07)\end{array}$ & $\begin{array}{l}-2226 \\
(1.23)\end{array}$ & 41 & 0.40 \\
\hline USA: 1919-1936 & $\begin{array}{l}0.163 \\
(0.07)\end{array}$ & $\begin{array}{c}1.95 \\
(2.58)\end{array}$ & $\begin{array}{l}-3.85 \\
(0.31)\end{array}$ & $\begin{array}{c}-40327 \\
(2.73)\end{array}$ & 17 & 0.71 \\
\hline DEN: 1870-1913 & $\begin{array}{c}1.51 \\
(0.34)\end{array}$ & $\begin{array}{l}0.242 \\
(1.01)\end{array}$ & $\begin{array}{c}1.04 \\
(0.95)\end{array}$ & $\begin{array}{l}-1785 \\
(1.86)\end{array}$ & 35 & 0.44 \\
\hline DEN: 1919-1936 & $\begin{array}{l}12.73 \\
(0.62)\end{array}$ & $\begin{array}{c}4.00 \\
(2.63)\end{array}$ & $\begin{array}{l}12.37 \\
(1.28)\end{array}$ & $\begin{array}{c}-52751 \\
(3.63)\end{array}$ & 11 & 0.85 \\
\hline FRA: 1870-1913 & ---- & $\begin{array}{l}0.277 \\
(1.62)\end{array}$ & $\begin{array}{c}8.08 \\
(0.99)\end{array}$ & $\begin{array}{c}-35070 \\
(3.91)\end{array}$ & 42 & 0.40 \\
\hline FRA: 1919-1936 & --- & $\begin{array}{l}0.408 \\
(0.41)\end{array}$ & $\begin{array}{l}-11.03 \\
(0.16)\end{array}$ & $\begin{array}{l}-9280 \\
(0.42)\end{array}$ & 15 & 0.29 \\
\hline GER: $1870-1913$ & $\begin{array}{c}5.53 \\
(0.88)\end{array}$ & $\begin{array}{l}-0.459 \\
(1.37)\end{array}$ & $\begin{array}{l}21.17 \\
(1.92)\end{array}$ & $\begin{array}{c}-19254 \\
(1.10)\end{array}$ & 32 & 0.46 \\
\hline ITA: $1870-1913$ & $\begin{array}{c}2.12 \\
(0.81)\end{array}$ & $\begin{array}{c}0.0988 \\
(0.37)\end{array}$ & $\begin{array}{c}-22.58 \\
(0.89)\end{array}$ & $\begin{array}{c}-13737 \\
(0.86)\end{array}$ & 42 & 0.22 \\
\hline ITA: $1919-1936$ & $\begin{array}{l}13.60 \\
(2.42)\end{array}$ & $\begin{array}{c}1.35 \\
(2.92)\end{array}$ & $\begin{array}{c}-48040 \\
(1.88)\end{array}$ & $\begin{array}{l}31.48 \\
(0.73)\end{array}$ & 17 & 0.83 \\
\hline NOR: $1870-1913$ & $\begin{array}{c}0.0001 \\
(0.16)\end{array}$ & $\begin{array}{l}-0.154 \\
(0.54)\end{array}$ & $\begin{array}{l}0.0835 \\
(0.13)\end{array}$ & $\begin{array}{c}-718 \\
(1.79)\end{array}$ & 27 & 0.40 \\
\hline NOR: 1919-1936 & $\begin{array}{c}0.0079 \\
(0.85)\end{array}$ & $\begin{array}{l}0.914 \\
(0.96)\end{array}$ & $\begin{array}{c}1.45 \\
(0.61)\end{array}$ & $\begin{array}{l}-4820 \\
(1.45)\end{array}$ & 17 & 0.24 \\
\hline SWE: 1870-1913 & $\begin{array}{l}0.686 \\
(0.72)\end{array}$ & $\begin{array}{l}0.424 \\
(1.39)\end{array}$ & $\begin{array}{c}1.97 \\
(1.77)\end{array}$ & $\begin{array}{l}-2837 \\
(2.54)\end{array}$ & 42 & 0.32 \\
\hline SWE: 1919-1936 & $\begin{array}{l}35.14 \\
(1.07)\end{array}$ & $\begin{array}{c}1.99 \\
(2.54)\end{array}$ & $\begin{array}{l}-3.73 \\
(1.41)\end{array}$ & $\begin{array}{c}-11017 \\
(1.97)\end{array}$ & 14 & 0.79 \\
\hline UK:1870-1913 & $\begin{array}{l}0.436 \\
(4.41)\end{array}$ & $\begin{array}{l}0.129 \\
(0.52)\end{array}$ & $\begin{array}{l}-0.373 \\
(0.61)\end{array}$ & $\begin{array}{l}-4218 \\
(3.10)\end{array}$ & 42 & 0.59 \\
\hline UK: 1919-1936 & $\begin{array}{c}1.76 \\
(2.14)\end{array}$ & $\begin{array}{l}0.549 \\
(0.65)\end{array}$ & $\begin{array}{c}1.97 \\
(1.41)\end{array}$ & $\begin{array}{l}-2872 \\
(2.64)\end{array}$ & 17 & 0.72 \\
\hline
\end{tabular}


Notes: The dependent variable (change in rltrade) is the first difference of the deflated sum of imports and exports. The migration variable (change in abmig) measures the first difference of the absolute value of gross immigration for New World countries (except Australia which reports net immigration) or gross intercontinental emigration for Old World countries. Adequate migration data are not available for France. The current account variable (change in abrlCA) measures the first difference of the absolute value of the deflated overall current balance. Data limitations preclude estimation for interwar Germany. The transport cost measure is the same for all countries and is also first differenced. The tariff measure is the first difference in custons revenue divided by import values.

Time and time squared terms are not reported in the table. All regressions are Cochrane-Orcuit. t-statistics are in parentheses. 
Table 1c: Time Series Factor Mobility Correlates with Trade, 1870-1913 and 1919 to 1936 Dependent Variable: Change in rltrade; Factor Mobility Variables: abmig and abrlCA

\begin{tabular}{|c|c|c|c|c|c|c|}
\hline & Migration & Curr.Act. & Tran.Cost & Tariff & $\mathrm{N}$ & $\mathrm{R}^{\wedge} 2$ \\
\hline AUS: $1870-1913$ & $\begin{array}{c}-0.0083 \\
(0.15)\end{array}$ & $\begin{array}{c}-0.0821 \\
(0.36)\end{array}$ & $\begin{array}{l}0.124 \\
(0.59)\end{array}$ & $\begin{array}{l}-140.6 \\
(1.37)\end{array}$ & 29 & 0.19 \\
\hline AUS: 1919-1936 & $\begin{array}{l}0.250 \\
(1.04)\end{array}$ & $\begin{array}{l}-0.819 \\
(4.00)\end{array}$ & $\begin{array}{c}0.010 \\
(0.04)\end{array}$ & $\begin{array}{l}-119.16 \\
(3.01)\end{array}$ & 15 & 0.76 \\
\hline CAN: $1870-1913$ & $\begin{array}{l}-0.460 \\
(0.76)\end{array}$ & $\begin{array}{l}0.713 \\
(2.54)\end{array}$ & $\begin{array}{l}-8.86 \\
(1.81)\end{array}$ & $\begin{array}{l}-13040 \\
(1.43)\end{array}$ & 13 & 0.53 \\
\hline CAN: 1919-1936 & $\begin{array}{c}0.126 \\
(0.02)\end{array}$ & $\begin{array}{c}0.728 \\
(0.59)\end{array}$ & $\begin{array}{l}19.29 \\
(1.22)\end{array}$ & $\begin{array}{l}-4212 \\
(0.39)\end{array}$ & 17 & 0.20 \\
\hline USA: $1870-1913$ & $\begin{array}{l}0.383 \\
(1.60)\end{array}$ & $\begin{array}{l}0.032 \\
(0.13)\end{array}$ & $\begin{array}{l}-1.16 \\
(0.23)\end{array}$ & $\begin{array}{l}-2982 \\
(1.48)\end{array}$ & 41 & 0.18 \\
\hline USA: 1919-1936 & $\begin{array}{l}-7.42 \\
(2.08)\end{array}$ & $\begin{array}{c}1.053 \\
(0.51)\end{array}$ & $\begin{array}{l}0.967 \\
(0.02)\end{array}$ & $\begin{array}{c}-13678 \\
(1.23)\end{array}$ & 17 & 0.45 \\
\hline DEN: $1870-1913$ & $\begin{array}{c}2.05 \\
(0.72)\end{array}$ & $\begin{array}{l}-0.163 \\
(0.65)\end{array}$ & $\begin{array}{c}1.52 \\
(1.57)\end{array}$ & $\begin{array}{l}-1853 \\
(2.04)\end{array}$ & 37 & 0.43 \\
\hline DEN: 1919-1936 & $\begin{array}{l}31.07 \\
(1.43)\end{array}$ & $\begin{array}{c}2.09 \\
(1.69)\end{array}$ & $\begin{array}{c}9.92 \\
(1.50)\end{array}$ & $\begin{array}{c}-31387 \\
(3.41)\end{array}$ & 13 & 0.74 \\
\hline FRA: $1870-1913$ & $=:=$ & $\begin{array}{l}0.183 \\
(1.48)\end{array}$ & $\begin{array}{c}3.75 \\
(0.47)\end{array}$ & $\begin{array}{c}-30751 \\
(3.30)\end{array}$ & 42 & 0.28 \\
\hline FRA: 1919-1936 & ---- & $\begin{array}{l}0.709 \\
(0.54)\end{array}$ & $\begin{array}{r}-11.16 \\
(0.17)\end{array}$ & $\begin{array}{l}-9198 \\
(0.42)\end{array}$ & 15 & 0.29 \\
\hline GER: $1870-1913$ & $\begin{array}{c}2.75 \\
(1.13)\end{array}$ & $\begin{array}{l}0.600 \\
(1.62)\end{array}$ & $\begin{array}{l}14.57 \\
(1.36)\end{array}$ & $\begin{array}{c}-46931 \\
(2.82)\end{array}$ & 32 & 0.57 \\
\hline GER: 1919-1936 & $\begin{array}{l}119.2 \\
(3.27)\end{array}$ & $\begin{array}{l}0.704 \\
(1.01)\end{array}$ & $\begin{array}{l}169.7 \\
(3.14)\end{array}$ & $\begin{array}{c}-49832 \\
(4.84)\end{array}$ & 9 & 0.97 \\
\hline ITA: 1870-1913 & $\begin{array}{c}2.24 \\
(1.29)\end{array}$ & $\begin{array}{l}0.182 \\
(1.02)\end{array}$ & $\begin{array}{l}-12.68 \\
(0.51)\end{array}$ & $\begin{array}{l}-8790 \\
(0.57)\end{array}$ & 42 & 0.23 \\
\hline ITA: 1919-1936 & $\begin{array}{l}32.87 \\
(2.22)\end{array}$ & $\begin{array}{l}-0.116 \\
(0.12)\end{array}$ & $\begin{array}{l}30.96 \\
(0.30)\end{array}$ & $\begin{array}{c}-79047 \\
(2.21)\end{array}$ & 17 & 0.58 \\
\hline NOR: $1870-1913$ & $\begin{array}{c}-0.0003 \\
(0.56)\end{array}$ & $\begin{array}{l}-0.356 \\
(1.96)\end{array}$ & $\begin{array}{l}0.0011 \\
(0.002)\end{array}$ & $\begin{array}{c}-632.29 \\
(1.68)\end{array}$ & 27 & 0.52 \\
\hline NOR: 1919-1936 & $\begin{array}{l}0.020 \\
(2.39)\end{array}$ & $\begin{array}{l}-1.31 \\
(2.09)\end{array}$ & $\begin{array}{l}-4.12 \\
(3.55)\end{array}$ & $\begin{array}{l}-2585 \\
(1.18)\end{array}$ & 17 & 0.71 \\
\hline SWE: 1870-1913 & $\begin{array}{l}0.676 \\
(1.06)\end{array}$ & $\begin{array}{r}-0.306 \\
(1.14)\end{array}$ & $\begin{array}{c}2.16 \\
(1.87)\end{array}$ & $\begin{array}{l}-3148 \\
(2.80)\end{array}$ & 42 & 0.33 \\
\hline SWE: 1919-1936 & $\begin{array}{l}45.28 \\
(3.57)\end{array}$ & $\begin{array}{r}-0.216 \\
(0.19)\end{array}$ & $\begin{array}{c}-8.86 \\
(3.72)\end{array}$ & $\begin{array}{c}-13153 \\
(3.91)\end{array}$ & 14 & 0.93 \\
\hline UK:1870-1913 & $\begin{array}{l}0.215 \\
(1.87)\end{array}$ & $\begin{array}{l}-0.383 \\
(1.86)\end{array}$ & $\begin{array}{l}-0.372 \\
(0.52)\end{array}$ & $\begin{array}{l}-4846 \\
(2.94)\end{array}$ & 43 & 0.37 \\
\hline UK: 1919-1936 & $\begin{array}{l}-0.867 \\
(0.63)\end{array}$ & $\begin{array}{c}1.58 \\
(1.18)\end{array}$ & $\begin{array}{c}0.501 \\
(0.29)\end{array}$ & $\begin{array}{l}-4900 \\
(3.71) \\
\end{array}$ & 17 & 0.63 \\
\hline
\end{tabular}


Notes: The dependent variable (change in rltrade) is the first difference of the deflated sum of imports and exports. The migration variable (abmig) measures the absolute value of gross immigration for New World countries (except Australia which reports net immigration) or gross intercontinental emigration for Old World countries. Adequate migration data are not available for France. The current account variable (abrlCA) measures the absolute value of the deflated overall current balance. The transport cost measure is the same for all countries. The tariff measure is customs revenue divided by import values. Time and time squared terms are not reported in the table. All regressions are Cochrane-Orcutt. $\mathbf{t}$-statistics are in parentheses. 
Table 2a: Trade and Factor Mobility, Time Series Complements or Substitutes? (c or s determined at 10 percent level of significance from Table 1a)

\begin{tabular}{lcccc}
\hline & \multicolumn{2}{c}{1870 to 1913} & \multicolumn{2}{c}{1919 to 1936} \\
& Labor & Capital & Labor & Capital \\
\hline AUS & $\mathrm{c}$ & $\mathrm{s}$ & $\mathrm{c}$ & $\mathrm{s}$ \\
CAN & $\mathrm{n}$ & $\mathrm{n}$ & $\mathrm{n}$ & $\mathrm{n}$ \\
USA & $\mathrm{c}$ & $\mathrm{n}$ & $\mathrm{n}$ & $\mathrm{c}$ \\
DEN & $\mathrm{n}$ & $\mathrm{n}$ & $\mathrm{n}$ & $\mathrm{c}$ \\
FRA & --- & $\mathrm{n}$ & ---- & $\mathrm{n}$ \\
GER & $\mathrm{n}$ & $\mathrm{n}$ & $\mathrm{c}$ & $\mathrm{c}$ \\
ITA & $\mathrm{c}$ & $\mathrm{s}$ & $\mathrm{c}$ & $\mathrm{c}$ \\
NOR & $\mathrm{n}$ & $\mathrm{n}$ & $\mathrm{n}$ & $\mathrm{s}$ \\
SWE & $\mathrm{n}$ & $\mathrm{n}$ & $\mathrm{c}$ & $\mathrm{c}$ \\
UK & $\mathrm{c}$ & $\mathrm{n}$ & $\mathrm{c}$ & $\mathrm{n}$ \\
\hline
\end{tabular}

Source: Taken from Table 1a. A positive and significant (at 10 percent level) coefficient relating trade to the factor flow variable in Table la is designated complementary. A negative and significant (at 10 percent level) coefficient on the factor flow variable is designated substitutable. Insignificant coefficients are designated neutral. 
Table 2b: Trade and Factor Mobility, Time Series Complements or Substitutes? (c or $\mathrm{s}$ determined at 10 percent level of significance from Table $1 \mathrm{~b}$ )

\begin{tabular}{ccccc}
\hline & \multicolumn{2}{c}{1870 to 1913} & \multicolumn{2}{c}{1919 to 1936} \\
& Labor & Capital & Labor & Capital \\
\hline AUS & $\mathrm{n}$ & $\mathrm{n}$ & $\mathrm{n}$ & $\mathrm{n}$ \\
CAN & $\mathrm{n}$ & $\mathrm{n}$ & $\mathrm{n}$ & $\mathrm{n}$ \\
USA & $\mathrm{c}$ & $\mathrm{n}$ & $\mathrm{n}$ & $\mathrm{c}$ \\
DEN & $\mathrm{n}$ & $\mathrm{n}$ & $\mathrm{n}$ & $\mathrm{c}$ \\
FRA & --- & $\mathrm{n}$ & ---- & $\mathrm{n}$ \\
GER & $\mathrm{n}$ & $\mathrm{n}$ & ---- & ---- \\
ITA & $\mathrm{n}$ & $\mathrm{n}$ & $\mathrm{c}$ & $\mathrm{c}$ \\
NOR & $\mathrm{n}$ & $\mathrm{n}$ & $\mathrm{n}$ & $\mathrm{n}$ \\
SWE & $\mathrm{n}$ & $\mathrm{n}$ & $\mathrm{n}$ & $\mathrm{c}$ \\
UK & $\mathrm{c}$ & $\mathrm{n}$ & $\mathrm{c}$ & $\mathrm{n}$ \\
\hline
\end{tabular}

Source: Taken from Table $1 \mathrm{~b}$. A positive and significant (at 10 percent level) coefficient relating trade to the factor flow variable in Table $1 \mathrm{~b}$ is designated complementary. A negative and significant (at 10 percent level) coefficient on the factor flow variable is designated substitutable. Insignificant coefficients are designated neutral. 
Table 2c: Trade and Factor Mobility, Complements or Substitutes?

(c or $\mathrm{s}$ determined at 10 percent level from table $1 \mathrm{c}$ )

\begin{tabular}{lcccc}
\hline & \multicolumn{2}{c}{1870 to 1913} & \multicolumn{2}{c}{1919 to 1936} \\
& Labor & Capital & Labor & Capital \\
\hline AUS & $\mathrm{n}$ & $\mathrm{n}$ & $\mathrm{n}$ & $\mathrm{s}$ \\
CAN & $\mathrm{n}$ & $\mathrm{c}$ & $\mathrm{n}$ & $\mathrm{n}$ \\
USA & $\mathrm{n}$ & $\mathrm{n}$ & $\mathrm{s}$ & $\mathrm{n}$ \\
DEN & $\mathrm{n}$ & $\mathrm{n}$ & $\mathrm{n}$ & $\mathrm{n}$ \\
FRA & $-\cdots$ & $\mathrm{n}$ & $-\cdots$ & $\mathrm{n}$ \\
GER & $\mathrm{n}$ & $\mathrm{n}$ & $\mathrm{c}$ & $\mathrm{n}$ \\
ITA & $\mathrm{n}$ & $\mathrm{c}$ & $\mathrm{c}$ & $\mathrm{n}$ \\
NOR & $\mathrm{n}$ & $\mathrm{s}$ & $\mathrm{c}$ & $\mathrm{s}$ \\
SWE & $\mathrm{n}$ & $\mathrm{n}$ & $\mathrm{c}$ & $\mathrm{n}$ \\
UK & $\mathrm{c}$ & $\mathrm{s}$ & $\mathrm{n}$ & $\mathrm{n}$ \\
\hline
\end{tabular}

Source: Taken from Table 1c. A positive and significant (at 10 percent level) coefficient relating trade to the factor flow variable in Table $1 \mathrm{c}$ is designated complementary. A negative and significant (at 10 percent level) coefficient on the factor flow variable is designated substitutable. Insignificant coefficients are designated neutral. 
Table 3. Trade and Factor Mobility Correlations:

Decade Averaged Panel Data for the Atlantic Economy, 1870 to 1940 Dependent Variable: trade/GDP

\begin{tabular}{|c|c|c|c|c|}
\hline & (1) & (2) & (3) & (4) \\
\hline \multirow[t]{2}{*}{ Emig. Rate } & 0.00169 & 0.000550 & -0.00218 & -0.00318 \\
\hline & $(0.56)$ & $(0.14)$ & $(1.09)$ & $(1.87)$ \\
\hline \multirow[t]{2}{*}{ CA/GDP } & -0.131 & -0.491 & 1.08 & 0.522 \\
\hline & $(0.23)$ & $(0.73)$ & $(3.35)$ & $(2.16)$ \\
\hline \multirow[t]{2}{*}{ Tariff } & -1.07 & -0.999 & -0.382 & -0.190 \\
\hline & $(4.94)$ & $(4.57)$ & $(3.49)$ & $(1.94)$ \\
\hline \multirow[t]{2}{*}{ Transport Cost } & -0.000140 & --- & 0.000212 & ---- \\
\hline & $(0.24)$ & & $(0.83)$ & \\
\hline \multirow[t]{2}{*}{ Endow. } & 0.0341 & 0.0355 & 0.0349 & 0.0120 \\
\hline & $(1.77)$ & $(1.85)$ & $(0.85)$ & $(0.29)$ \\
\hline \multirow[t]{2}{*}{ Constant } & 0.449 & 0.438 & 0.315 & 0.430 \\
\hline & $(6.53)$ & $(13.67)$ & $(6.04)$ & $(12.47)$ \\
\hline Country Dummies & No & No & Yes & Yes \\
\hline Time Dummies & No & Yes & No & Yes \\
\hline $\mathbf{N}$ & 58 & 58 & 58 & 58 \\
\hline$R^{2}$ & 0.33 & 0.34 & 0.91 & 0.95 \\
\hline
\end{tabular}

Notes: The factor flow variables are the absolute value of the net emigration rate and the absolute value of the current account divided by GDP. The transport cost variable is the same for all countries (and therefore drops out when time dummies are included). The tariff variable is customs revenue divided by import values. The calculation of the "endowment distance" variable is described in the text. Standard errors are adjusted for heteroskedasticity. t-statistics are in parentheses. 
Table 4. The Determinants of Immigration Policy, c1860-1930

Dependent variable: POLICY

Variable

Coefficient

(t-statistic)

Lagged dependent variable: POLICY $(-1)$

$0.809 * * *$

$(9.744)$

Lagged ratio wage to GDP per worker: $w / y(-1)$

$0.015 * * *$

$(2.646)$

Lagged real wage of the unskilled: WAGER(-1)

0.005

$(0.637)$

Unemployment rates: UNEMP

0.009

(1.242)

Trade share measure of "openness": $[X+M] / Y$

0.005

$(0.800)$

Lagged unskilled wage, immigrant origin: IMWAGE(-1) $\quad-0.028$ *

$(1.896)$

Lagged immigrant supply threat: THREAT(-1)

$-0.847 *$ *

$(2.573)$

$\mathrm{R}^{2}$

Adjusted $\mathrm{R}^{2}$

0.867

0.839

S.E. of regression

0.911

Number of observations

56

Source: Timmer and Williamson (1996).

Notes: $* * *$ refers to $1 \%, * * 5 \%$ and $* 10 \%$ significance levels. POLICY measures liberal $(+5)$ versus restrictive $(-5)$ policies towards immigration. Unit of observation is half-decade. Estimated by fixed effects, although the fixed effects coefficients are excluded from the table. See text. 


\section{Data Appendix}

Most of the data is available in the following volumes of historical statistics compiled by B.R. Mitchell: International Historical Statistics: Europe 1750-1988 (hereafter IHSE); International Historical statistics - The Americas (hereafter IHSA); International Historical Statisticg - Africa, Asia and Oceania (hereafter IHSAAO); and International Historical statistics - The Americas and Australasia (hereafter IHSAA).

Imports and Exports: Generally, statistics are for merchandise trade only, and imports are valued c.i.f. whereas exports are valued f.o.b. European $f$ igures are from Mitchell, IHSE. Complete data are unavailable for Germany before 1880, and from 1871 to 1918 Alsace Lorraine is included in Germany rather than France. Trade between Ireland and Britain is treated as international trade beginning in 1923, Canadian and US figures are from Mitchell, IHSA. Australian figures are from Mitchell, IHSAAO. GDP deflators are used to convert nominal trade figures to real trade figures in the "long swing" section of the paper.

GDP (nominal): Current price GDP (or GNP) figures are used to scale the Current price trade figures in the panel data section of the paper. European figures are from Mitchell, IHSE. Germany's statistics are for net national product. Ireland is excluded from the UK total beginning in 1921 . US figures are from Mitchell IHSA. Canadian figures were extracted from data provided by Michael Bordo and used in Bordo and Jonung (1987). Australian figures are from Mitchell IHSAAO.

Transport costs: Calculated from Isserlis (1938), Table VIII. The nominal freight index (column 2) is deflated by the statist wholesale price index (column 6).

GDP (real): GDP levels measured in million 1990 Geary-Khamis dollars are taken from Maddison, 1995, appendix C. Maddison (1995) reports GDP for the Federal Republic area only, and so overall German figures were calculated by multiplying income per capita (Maddison 1995, appedix D) by the population figures described below.

Population: For Australia, Denmark, France, Italy, Norway, and Sweden, annual population figures are from Maddison, 1995, appendix A. For Canada, Germany, the UK and the US, annual population figures are from Maddison, 1991, appendix B. The UK figures include Ireland (from Maddison 1995) throughout the period.

Land: Agricultural land is taken from Estevedeordal (1993, p. 64). The figures are based on a League of Nations study for 1913 which defined agricultural land as "arable land, pasture, meadow and prairie, trees, shrubs and bushes, but not forests" (Estevedeordal, p. 21). These quantities are assumed constant over time.

Coal: Coal consumption is calculated as the sum of coal production plus coal imports minus coal exports. Brown coal is converted to hard coal equivalents using conversion factors taken from Darmstadter (1971, p. 828) for each country. European data for production and trade are from Mitchell, IHSE. Canadian and US production and trade figures are from Mitchell, IHSAA. Australian production figures are from Kalix, et al. (1966) and trade figures are from Mitchell, IHSAA.

Tariff Revenue: European figures are from Mitchell, IHSE. Italian tariffs for 1870 to 1929 were kindly provided by Giovanni Federico. Canadian and Us data are from Mitchell, IHSA. Tariff rates for Australia prior to 1901 are constructed from customs and import data available in the Victorian Year-Book (various editions) for Victoria. Beginning in 1901, Australian customs revenue figures are available in Mitchell, IHSAAO. 
Current Account: The overall current balance for European countries is from Mitchell, IHSE. Australian, Canadian and US figures are from Mitchell, IHSAA. The Canadian series does not begin until 1900.

Gross miqration (annual): Gross annual emigration (Old World) or immigration (New World) figures are used in the time series analysis. These statistics relate to intercontinental migration. In general, it is not possible to construct reliable net migration figures on an annual basis. European statistics are from Mitchell, IHSE. Canadian and us statistics are from Mitchell, IHSA. Australian migration figures are reported as net immigrants (that is, immigration and emigration are not reported separately) in Mitchell, IHSAAO.

Net emiqration (decade): For most countries these figures were estimated using a combination of census population figures and average annual rates of natural increase as described in detail in the text. However, Italian figures are taken from Bacci (1978), Australian figures are derived from the net immigration series in Mitchell, IHSAAO, and the Us figures are from Eldridge and Thomas (1964). The UK figures are constructed to include Ireland throughout the period by using Mitchell (1988) British Historical Statistics. The panel data section of the paper uses net emigration rates where average annual emigration is expressed as a rate per 1,000 population at the period's beginning. 


\section{References}

Abramovitz, M. (1961), "The Nature and Significance of Kuznets Cycles," Economic Development and Cultural Change 9, 3: 225-48.

Anderson, J. and J. P. Neary (1994), "Measuring the Restrictiveness of Trade Policy," The World Bank Economic Review 8: 151-69.

Bacci, M. L. (1978), "Fattori Demographici Dello Sviluppo Economico" in G. Fua (ed.) Lo Sviluppo Economico in Italia, Vol. II (Milan: F. Angeli). Bordo, M. and L. Jonung (1987), The Long-Run Behavior of the Velocity of Circulation (Cambridge: Cambridge University Press).

Cairncross, A. (1953), Home and Foreign Investment (Cambridge: Cambridge University Press).

Corden, W. M and J. P. Neary (1982), "Booming Sector and De-Industrialization in a Small Open Economy," Economic Journal 92: 825-48.

Darmstadter, J. (1971), Energy in the World Economy (Baltimore: Johns Hopkins Press).

Easterlin, R. A. (1966), "Economic-Demographic Interactions and Long Swings in Economic Growth," American Economic Review 56:

--- (1968), Population, Labor Force and Long Swings in Economic Growth (New York: National Bureau of Economic Research) .

Eldridge, H. and D. Thomas (1964), Population Redistribution and Economic Growth, United States, 1870-1950: Demographic Analyses and Interrelations (Philadelphia: American Philosophical Society).

Estevadeordal, A. (1993), Historical Essays on Comparative Advantage (Harvard University PhD Thesis, unpublished).

Findlay, R. F. (1995), Factor Proportions, Trade, and Growth (Cambridge, Mass.: MIT).

Flam, H. and M. J. Flanders (1991), Heckscher-Ohlin Trade Theory (Cambridge, Mass.: MIT Press).

Foreman-Peck, J. (1992), "A Political Economy Model of International Migration, 1815-1914," The Manchester School, 60, 4: 355-76. 
Goldin, C. (1994), "The Political Economy of Immigration Restriction in the U.S., 1890 to 1921," in C. Goldin and G. Libecap (eds.), The Requlated Economy: A Historical Approach to Political Economy (Chicago: The University of Chicago Press).

Grubert, H. and J. Mutti (1991), "Taxes, Tariffs and Transfer Pricing in Multinational Corporate Decisions Making," Review of Economics and statistics $73: 285-93$.

Hatton, T. J. and J. G. Williamson (1997), The Age of Mass Migration: An Economic Analysis (New York: Oxford University Press).

Heckscher, E. (1919), "The Effect of Foreign Trade on the Distribution of Income," Ekonomisk Tidskrift: 497-512.

International Bank for Reconstruction and Development (1995), World Development Report 1995 (New York: Oxford University Press). Isserlis, L. (1938), "Tramp shipping Cargoes and Freights," Journal of the Royal statistical Society 101, Pt. 1: 304-417.

Jones, R. W. (1971), "A Three-Factor Model in Theory, Trade, and History," in J. N. Bhagwati et al. (eds), Trade, Balance of Payments, and Growth (Amsterdam: North-Holland): 3-21.

Kalix, Z. (1966), Australian Mineral Industry: Production and Trade, 1842-1964 (Canberra: Bureau of Mineral Resources, Geology and Geophysics).

Kemp, M. C. and M. Ohyama (1978), "On the sharing of Trade Gains by ResourcePoor and Resource-Rich Countries," Journal of International Economics 8: $93-115$

Kelley, A. C. and J. G. Williamson (1984), what Drives Third World City Growth? (Princeton, NJ: Princeton University Press) .

Kuznets, s. (1930), Secular Movements in Production and Prices (New York: National Bureau of Economic Research).

--- (1958), "Long Swings in the Growth of population and in Related Economic Variables," Proceedings of the American Philosophical society 102, 1: 25-52.

Landes, D. S. (1969), The Unbound Prometheus (Cambridge: Cambridge University Press). 
Lerner, A. P. (1952), "Factor Prices and International Trade," Economica 19, $73: 1-15$.

Lewis, W. A. (1978), The Evolution of the International Economic Order (Princeton, NJ: Princeton Unviersity Press).

Lewis, W. A. and P. J. O'Leary (1955), "Secular Swings in Production and Trade, 1870-1913," Manchester School of Economic and Social studies $13,2: 113-52$.

Maddison, A. (1991), Dynamic Forces in Capitalist Development: A Long-Run Comparative View (New York: Oxford University Press). --- (1995), Monitoring the World Economy, 1820-1992 (Paris: OECD).

Markusen, J. R. (1983), "Factor Movements and Commodity Trade as Complements," Journal of International Economics 13: 341-56.

Mitchell, B. R. (1983), International Historical Statistics: The Americas and Australasia (Detroit: Gale Research Co.).

--- (1988), British Historical Statistics (New York: Cambridge University Press).

--- (1992), International Historical Statstics: Europe, 1750-1988 (New York: Stockton Press).

--- (1993), International Historical Statistics: The Americas, 1750-1988 (New York: Stockton Press).

--- (1995), International Historical Statistics: Africa, Asia \& Oceania, 17501988 (New York: Stockton Press).

Mundell, R. A. (1957), "International Trade and Factor Mobility," American Economic Review 47, 3: 321-35.

Neary, J. P. (1995), "Factor Mobility and International Trade," Canadian Journal of Economics 28, special issue: s4-s23.

O'Rourke, K. H. (1997), "Measuring Protection: A Cautionary Tale," Journal of Development Economics forthcoming.

O'Rourke, K. H. and J. G. Williamson (1997), "Around the European Periphery 1870-1913: Globalization, Schooling and Growth," European Review of Economic History forthcoming. 
Rostow, W. W. (1978), World Economy: History and Prospect (Austin, Texas: University of Texas Press).

Rybczynski, T. M. (1955), "Factor Endowments and Relative Commodity Prices," Economica 22, 88: 336-41.

Sachs, J. D. and A. Warner (1995), "Economic Reform and the Process of Global Integration," Brookings Papers on Economic Activity 1: 1-118.

Samuelson, P. A. (1949), "International Factor-Price Equalization Once Again," Economic Journal 59, $234: 181-97$.

--- (1995b), "Economic Convergence and Economic Policies," NBER Working Paper No. 5039, National Bureau of Economic Research, Cambridge, MA (February).

Schmitz, A. P. and P. Helmberger (1970), "Factor Mobility and International Trade: The Case of Complementarity," American Economic Review 60, 4 : 761-7.

Shughart, W., R. Tollison, and M. Kimenyi (1986), "The Political Economy of Immigration Restrictions," Yale Journal on Requlation, 51, 4 :

Taylor, A. M. (1996), "International Capital Mobility in History: The SavingInvestment Relationship," NBER Working Paper No. 5743, National Bureau of Economic Research, Cambridge, MA. (September).

Taylor, A. M. and J. G. Williamson (1994), "Capital Flows to the New world as an Intergenerational Transfer," Journal of Political Economy 102, 2: $348-71$

Temin, P. (1966), "Labor Scarcity and the Problem of American Industrial Efficiency," Journal of Economic History 26: 277-98.

Thomas, B. (1954), Migration and Economic Growth (Cambridge: Cambridge University Press).

Thomas, D. S. (1941), Social and Economic Aspects of Swedish Population Movements (New York: Macmillan).

Thompson, H. (1985), "Complementarity in a simple General Equilibrium Production Model," Canadian Journal of Economics 18, 3: 616-21. --- (1986), "Free Trade and Factor-Price Polarization," European Economic Review 30: 419-25. 
Timmer, A. and J. G. Williamson (1996), "Racism, Xenophobia or Markets? The Political Economy of Immigration Policy Prior to the Thirties," NBER Working Paper No. 5867, National Bureau of Economic Research, Cambridge, MA. (December).

--- (1997), "Immigration Policy Prior to the Thirties: Labor Markets, Policy Interactions and Globalization Backlash," Department of Economics, Harvard University (March).

United states Bureau of the Census (1975), Historical statistics of the United States, Colonial Times to 1970 (Washington: GPO).

Urquhart, M. C. (1965), Historical Statistics of Canada (Cambridge: Cambridge University Press).

Venables, A. J. (1997), "Trade Liberalization and Factor Mobility: An Overview," in this volume.

Wilkinson, M. (1967), "Evidences of Long Swings in the Growth of Swedish Population and Related Economic Variables 1860-1965," Journal of Economic History 27, 1: 17-38.

Williams, J. H. (1929), "The Theory of International Trade Reconsidered," Economic Journal 39, 154: 195-209.

Williamson, J. G. (1964), American Growth and the Balance of Payments, 1820-

1913 (Chapel Hill, North Carolina: University of North Carolina Press). --- (1974), "Migration to the New world: Long Term Influences and Impact," Explorations in Economic History 11, 4: 357-90.

--- (1996), "Globalization, Convergence, and History," Journal of Economic History $56: 277-306$.

Zevin, R. B. (1992), "Are World Financial Markets More Open? If So why and With What Effects?" in Financial Openness and National Autonomy, $r$. Banuri and J. Schor (eds.) (Oxford: Oxford University Press). 